\title{
Library Use and Information-Seeking Behaviour of Academics at Lincoln University
}

By

\section{Ying (Amanda) HE}

Submitted to the School of Information Management,

Victoria University of Wellington

in partial fulfilment of the requirements for the degree of

Master of Information Studies

\section{October}

2012 


\section{Table of Contents}

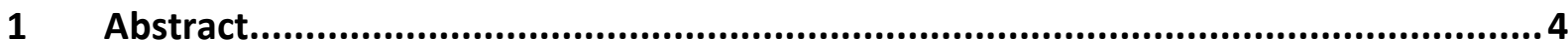

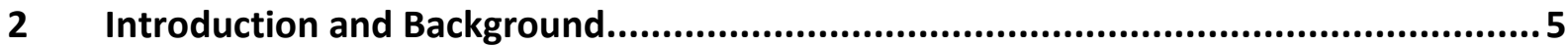

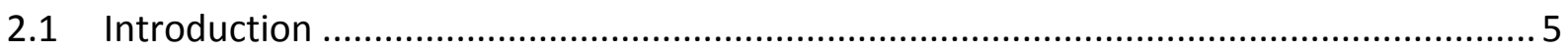

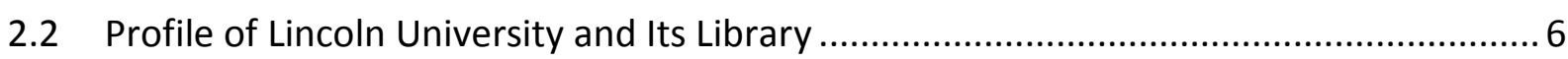

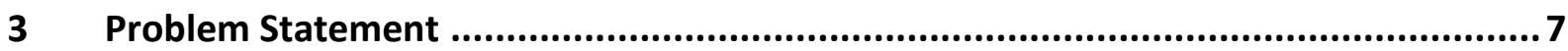

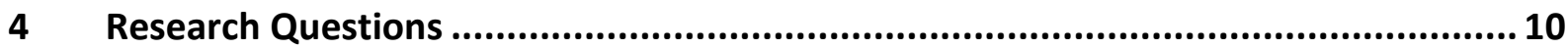

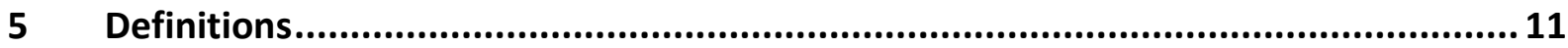

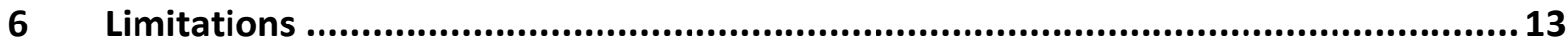

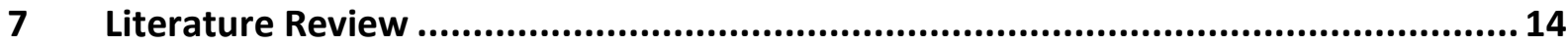

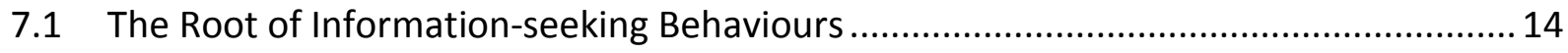

7.2 Disciplines and Information-seeking Behaviours.................................................... 16

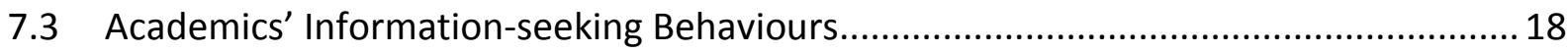

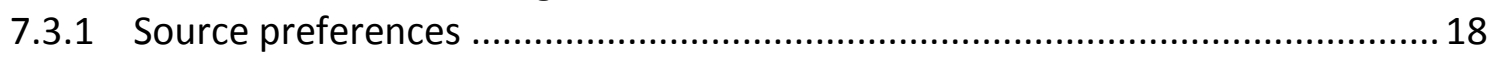

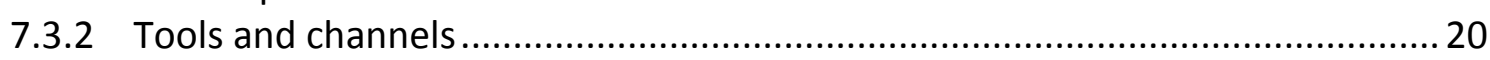

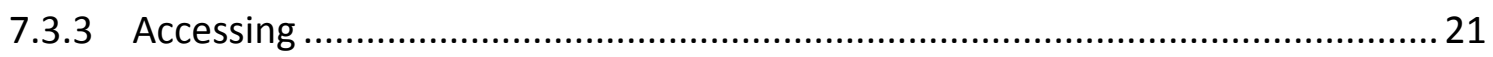

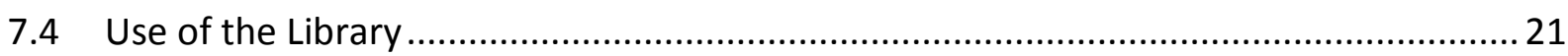

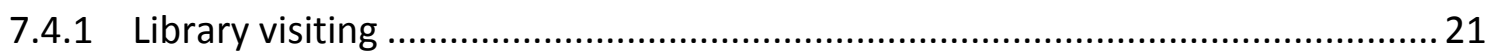

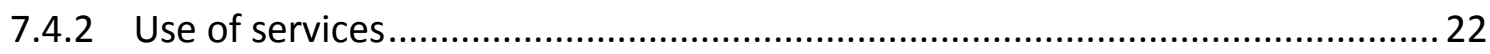

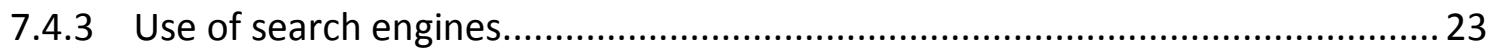

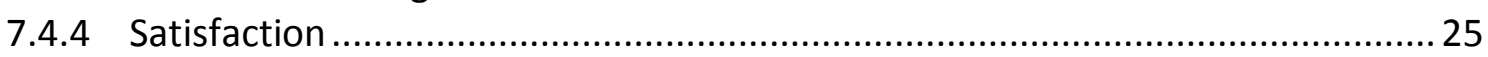

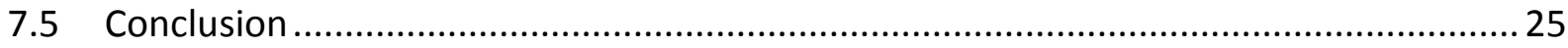

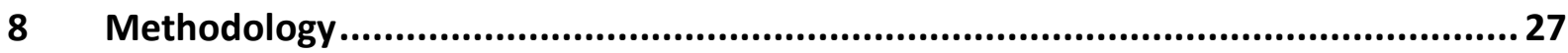

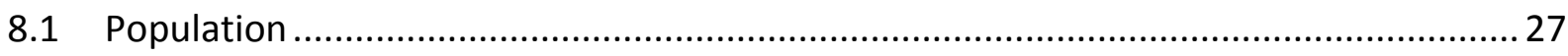

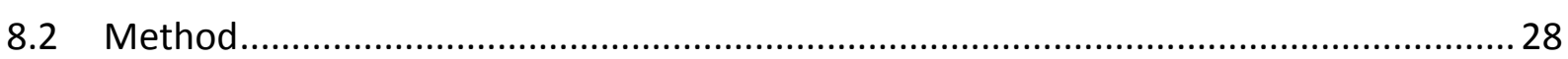

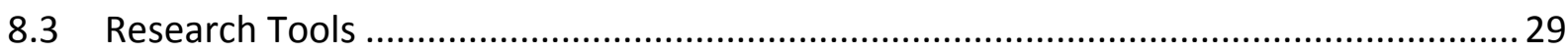

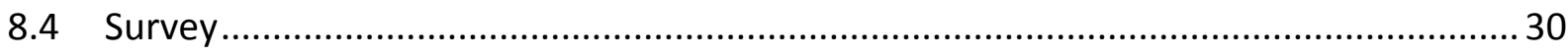

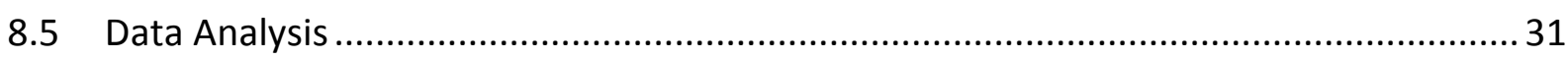

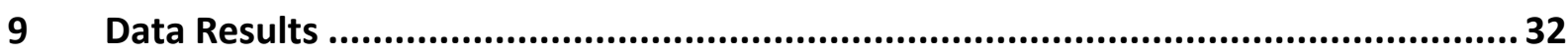

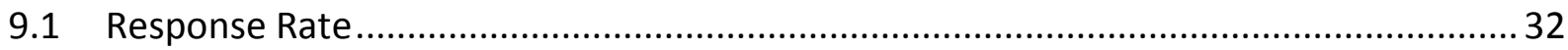

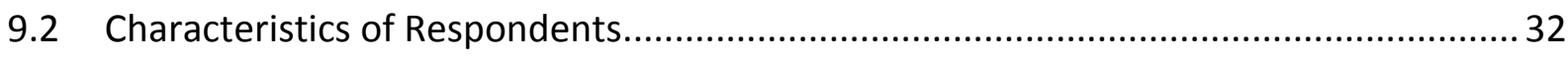

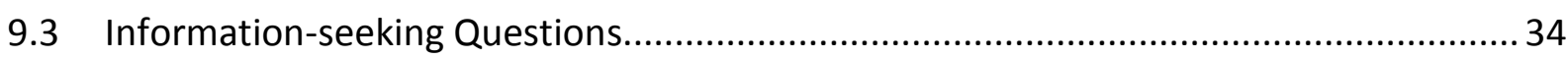

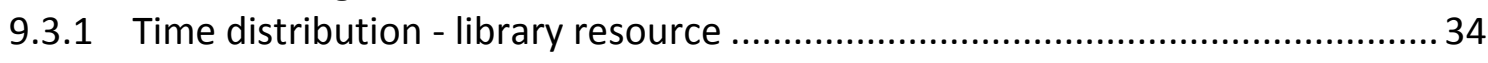

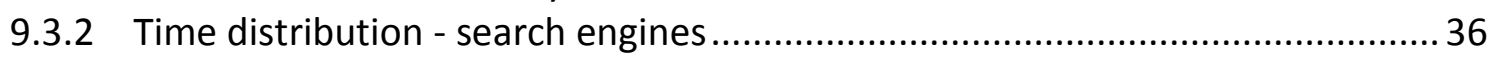

9.3.3 Preference - format, device and method ................................................. 38 


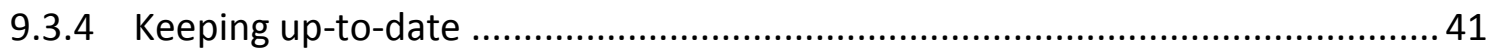

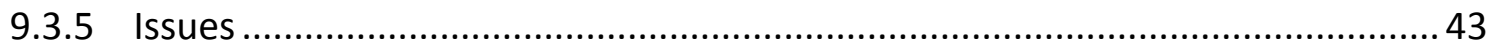

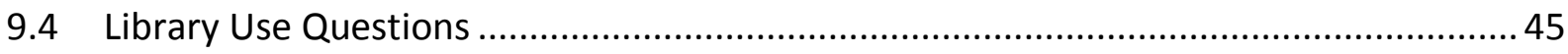

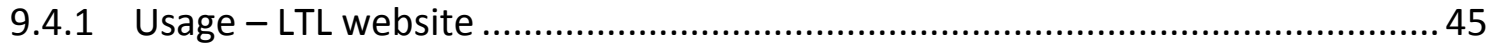

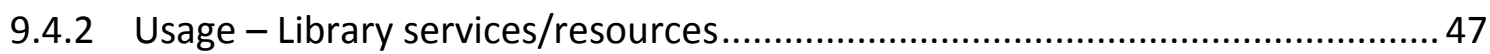

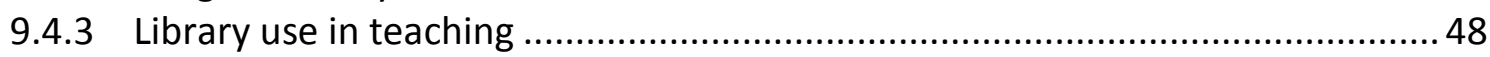

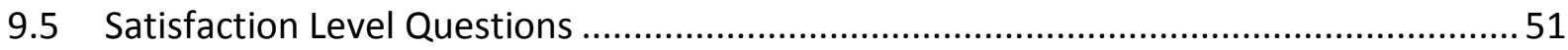

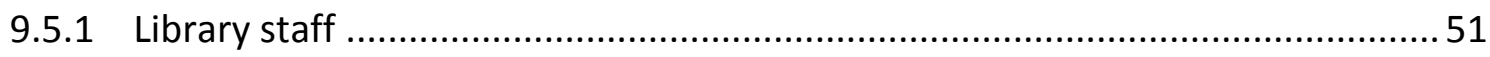

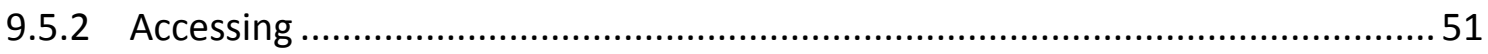

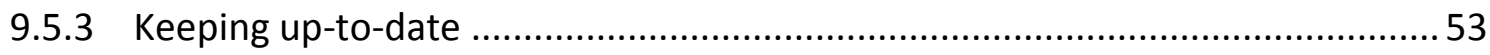

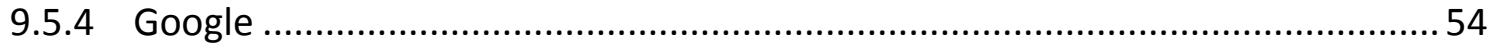

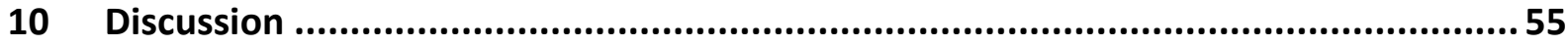

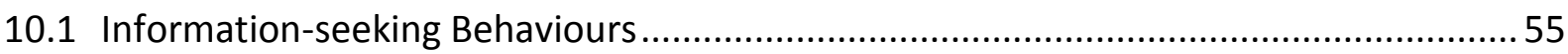

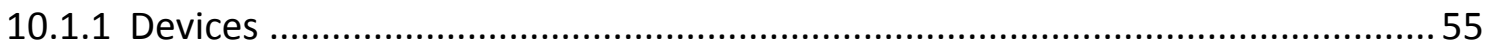

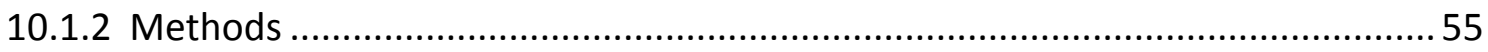

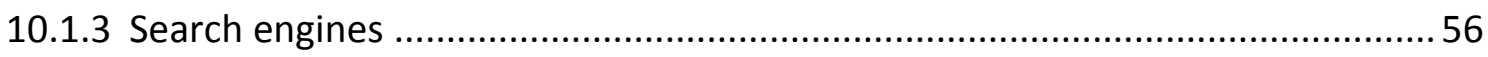

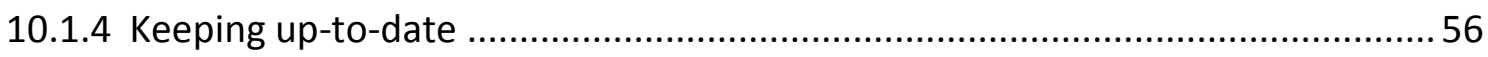

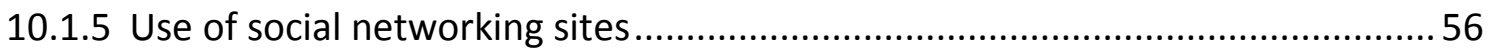

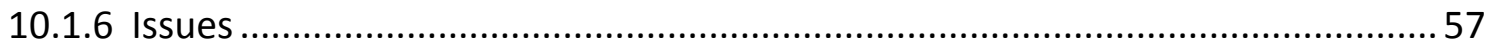

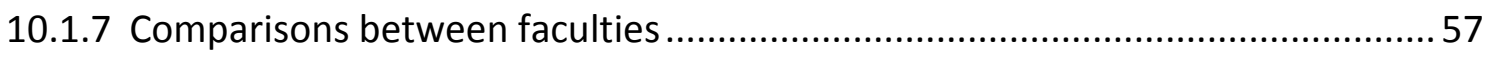

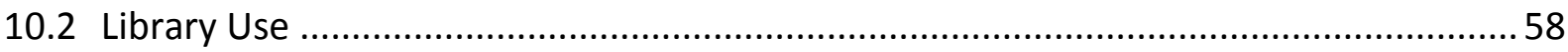

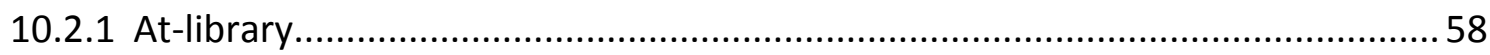

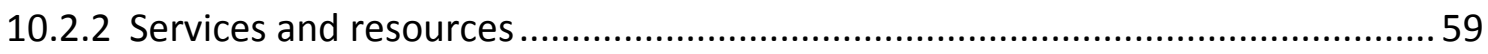

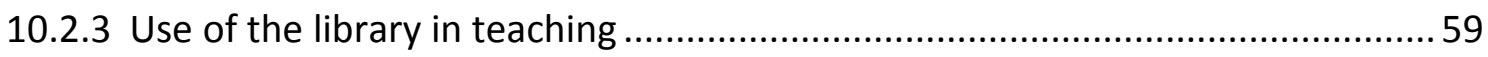

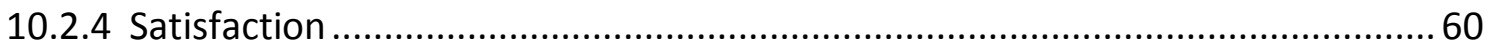

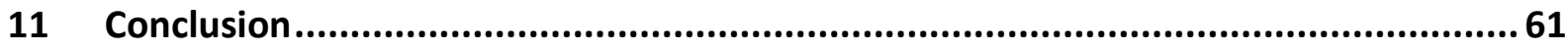

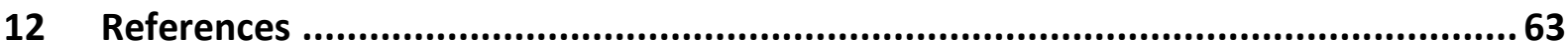

Appendix A Information Sheet and Reminder Email ................................................... 71

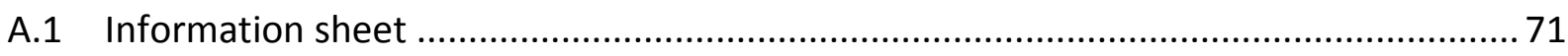

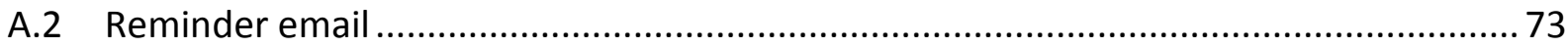

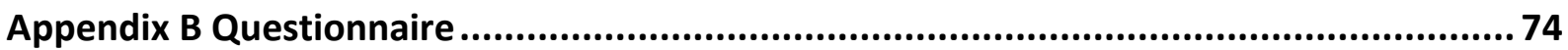




\section{Abstract}

Academics are an important user group for their university libraries. Academic libraries are trying very hard to balance limited funding and users' needs, especially while the information-seeking behaviour of academics is being changed by electronic resources. This study was undertaken to discover the information-seeking behaviour of academics and their use of the library at Lincoln University of New Zealand. The results from this study will be useful to enhance the collection development and prioritise programs and services to meet academics' needs more effectively.

An online survey was used for this study. All academics from the Faculty of Agriculture and Life Sciences, the Faculty of Commerce and the Faculty of Environment, Society and Design were selected and 49 academics responded.

The results indicated that a great number of academics depend on libraries for getting information. Academics are facing a big problem regarding the lack of time to obtain information. They also display great interest in using online journal articles and printed books from Lincoln University Library. However, academics are not interested in using the latest tools, such as smart phones, e-Pads etc. It was also established that academics from different disciplines have a very similar information-seeking behaviours. In addition, academics are satisfied with the library resources and services but they do not use it as much as they recommend it to students. Finally, academics have little contact with library staff.

Based on these findings, it was recommended that library resources should continue to have both electronic resources and printed resources. Librarians and library systems must do better to improve the time lost in information-seeking by academics. There is a need to improve the communication and collaboration between librarians and academics to encourage academics to use more library resources in their teaching, and librarians should encourage academics to learn the latest information-seeking tools and skills, as well as promote the library services and resources more.

Key words: $\quad$ Academics; Academic library; Information-seeking behaviors; Library use 


\section{Introduction and Background}

\subsection{Introduction}

Nowadays, there are multiplicities of sources in use for information-seeking and the modern ways of accessing information have impacted of on academic institutions. This means the information needs of the academic staff have changed and grown ("Need for academic libraries grows," 2011). With new technological developments and innovations come new challenges and new prospects. The academic library, as a service centre, has for centuries played a critically-important role in developing collections, services, and organizational structures that facilitate users needs. Brown (2010) conducted a study on scholarly communication in the digital world. The study claimed that the internet and informationsharing systems brought convenience into scholarly communication. Researchers nowadays have the ability to access their work, data and make contact with each other $24 / 7$ and across the world in a digital format. The technologies give the researcher gateway tools to relevant information that are not just tools to information but also to people. Brown shows that the new technologies make a significant impact on scholarly communication as it has brought people closer in virtual communication. It is clear that the new information technology will bring users new information-seeking patterns. In order to develop better collections and services to meet users' new expectations, the understanding of users' information needs is the key to it (Mackenzie, 2012). It is important that librarians are assigned to the needs of specific departments in order to support and advise teaching, learning and research in all subjects and disciplines (Research Information Network \& The Consortium of Research Libraries, 2007).

In this study, the main aims are to find out academic's information-seeking behaviours and whether academics make the optimum use of library services and resources.

The objectives of the study are as follows:

- Discover the types and channels in information-seeking most-used by academics.

- Identify the differences and similarities among disciplines in information-seeking behaviours. 
- Determine the importance of library resources and services in meeting the information needs.

- Identify the satisfaction of academics in using Lincoln University Library resources.

The results from this study will be useful to enhance collection development and design programs and services to meet academics' needs more effectively.

\subsection{Profile of Lincoln University and Its Library}

Lincoln is New Zealand's third oldest university. Founded in 1878 as a School of Agriculture (Lincoln University, 2012), the delivery of teaching and research is the responsibility of the University's four faculties and the Foundation Studies and English Language Centre.

The Lincoln University Library is one of the legal depositories of material in New Zealand and functions as a National Reference Library. The collection has been growing steadily at an average rate of 10,000 volumes per year. The Library is focusing on serving student and staff needs in learning, teaching and research. The Library also plays an important role in planning an information infrastructure that will ensure intellectual assets are both preserved and accessible in an appropriate way to as wide an audience as possible, both nationally and internationally, matching the University Librarian Professor Penny Carnaby's vision for 2020 with "connecting the knowledge networks, reimagining learning, teaching and research at Lincoln University to $2020 "$. Lately, the library introduced a new search engine called "Library Search", which is a one-stop search of a range of the Library's resources, including the Lincoln University Library catalogue, most library databases and the Lincoln University archive collection. Lincoln University Library also introduced a virtual help system called "Ask us", which is a one-stop online place where students and staff can ask a range of questions.

The Lincoln University Student Learning Centre joined the Library last year and the library now is called Library, Teaching and Learning (LTL). To clarify, this study is only about the Library side of Library, Teaching and Learning at Lincoln University. 


\section{Problem Statement}

Throughout the long history of information-seeking behaviours in academic libraries, many reasons for the need to study users' information-seeking behaviours have been presented in the literature.

\section{Needs to study academics}

Academics are a key user group and have played an important role in academic libraries. It has been said that “...an academic library's most powerful constituents are faculty and administrators" (Stebelman, 1999) because higher education courses are offered and controlled by academics. The library has strong roles in supporting learning, teaching and research, and the library collection must mainly focus on what academic staff are teaching and on research (T. D. Wilson, 2000). Academics also are the priority for librarians to study because they are "...the primary foundation of knowledge and education for students at institution of higher learning" (Ocak, 2011). Academics are the leaders in using information resources and systems because of their role in teaching and research in higher education (Martinez-Uribe \& Macdonald, 2009). Mohsenzadeh (2009) claimed that an academic library is a component of education systems which has an important role in providing better services and access to electronic information sources, helping academics in using the latest technology in their teaching and research, and helping academics to increase their skills in using the latest information systems. Librarians have a strong role in understanding, managing and taking responsibility for the key user information needs within a complex dynamic environment. Therefore, it is important to report current academics' information seeking behaviour and their use of the library in order to keep up with the latest teaching and research needs.

\section{Collection and services development}

Some writers believe understanding users' information needs will benefit the library's collection development. Evans (2002) pointed out that an academic library's collection development should focus on the curricula and research to support their users. Horava (2010) highlighted that collection development needs to be based on how users will use resources and services for the library. He also states "... collection management needs to be 
seen in terms of how we create rich, interactive spaces (both virtual and physical) in which the value of our resources can easily integrate into the scholarly communication behaviour and research workflow of our patrons." Others point out there is a need to allocate library resources appropriately. Librarians need to provide the needs of users and make choices to manage scholarly resource collections based on a realistic understanding of users' needs for both virtual and physical resources (Courtright, 2007). Palmer and Sandler (2003) claimed that once the library knows what was used and what was not in the library, it will help to produce a comprehensive collection and reproduce the best interest to their users and prevent a financial crisis in the long term. Song (2009) conducted a study on designing library services based on user needs. He pointed out that the library needs to continue working on users' needs in information seeking because users' needs change continuously.

\section{Best funding allocation}

Limited funding makes it difficult for the library to offer all the latest information technologies for their users (Stoller, 2005). Many libraries are facing budget cuts in acquisitions while they have the largest investment in digital resources and services, also maintaining the continuing expenditures for print (Stoller, 2005). The pressure of limited funding makes it harder for the library to meet their users' information needs. It also makes it difficult for the library to offer the virtual environment of learning and teaching. The understanding of users' information-seeking behaviours can be used for librarians to provide the most suitable services to support their users. Matusiak (2006) stated that academic libraries already faced challenges in budgets cuts as well as the high cost of electronic resources and information-seeking tools. In the long term, it will be more challenging for libraries to provide the latest technologies to support higher education. The library should have ideas about what will be most-used in their library in order to offer better services. Westbrook and Tucker (2002) discovered that the understanding of faculty members' information needs improves the library's decision-making. Sun, Chen, Tseng and Tsai (2011) conducted a study on how librarians collaborated with faculty members in the new information technology era. Their study indicated that the lack of funding is one of the biggest challenges for librarians to keep up with the latest information technologies. However, librarians are pushed to work on "long term strategies for supporting just in time technologies (Sun et al., 2011, p. 330)". Therefore, understanding users' information-seeking 
behaviours will help improve the library service to keep up with the most valuable information system in a digital age with limited funding.

Although numerous studies have been undertaken in information-seeking behaviour in a range of user groups and contexts, there is a gap in the research on information behaviour and whether academics make optimum use of libraries in the New Zealand University academic context and specifically in an agriculture university. No study to date has been conducted at Lincoln University of New Zealand to find out the information needs and information-seeking behaviour of academic members and their use of the library. To fill this knowledge gap, this study is one small contribution to this end. It will update insights on how the Lincoln University academics obtain professional information and make use of the library in relation to teaching. 


\section{Research Questions}

The study seeks to understand how academics are using the library in information-seeking. The research questions for this study are:

- What are the most-used devices, methods and resources by academics in information seeking?

- What are the similarities and differences among disciplines in obtaining information?

- How do academics get the latest information in their field?

- What are the biggest difficulties experienced by academics in information seeking?

- What Lincoln University Library services and resources are most-used by academics?

- Do academics often use Lincoln University Library both online and by physically going there?

- How many Lincoln University Library resources are used in teaching by academics?

- What is the satisfaction level of academics in using Lincoln University Library services and collections? 


\section{Definitions}

The phrases "information-seeking" and "Information-seeking behaviours" have been defined by many authors.

\section{Information-Seeking}

The term 'information-seeking', is defined by Marchionini (1995) as "...a process in which humans purposefully engage in order to change their state of knowledge". The informationseeking process allows people to identify their own needs for information, to search and to use or transfer that information. It is a key skill for people who are working in higher education. It can be conducted in many different activities in which people participate, and manifest through particular behaviours. Case $(2002$, p. 5) described "information-seeking" as "... a conscious effort to acquire information in response to a need or gap in your knowledge". Kuhlthau (2004) states "... the process of construction within information seeking involves fitting information in with what one already knows and extending this knowledge to create new perspectives". Most importantly, she suggested that the library is an important part of the information-seeking process because the information-seeking process pushes users to discover and use the library information services more.

\section{Information-Seeking Behaviour}

According to Krikelas (1983), information-seeking behaviour refers to "...any activity of an individual that is undertaken to identify a message that satisfies a perceived need." Wilson (T. D. Wilson, 1999) defines it, "...those activities a person may engage in when identifying their own needs for information, searching for such information in any way, and using or transferring that information". Case (2002) states "...information seeking behaviour encompasses information behaviour but the totality of unintended or passive behaviour....as well as purposive behaviour that do not involve seeking."

In summary, information-seeking is about the user's need for information and how users process their needs. Information-seeking behaviour refers to individual characteristics and actions in the information-seeking process. It usually involves personal reasons, methods and knowledge of information searching, information-seeking education and the effective use of information. Most times academic's information-seeking behaviours involves active or 
purposeful information-seeking as a result of the need to enhance their teaching and research, career development and so on.

\section{Academics}

An academic can be defined as one who is currently working in an academic area at Lincoln University, such as professors, lectures, research assistants, tutors and so on. According to this research, academics fulfil the purpose of being respondents to the research. In this scope, academics are the important users of the library at Lincoln University. 


\section{Limitations}

This research has it own limations as described below:

- The e-surveying method requires responders to have basic computer skills, access to the internet and a Lincoln University email address.

- The structured questionnaire has limitations in the types of questions and answers. Future studies to collect data via open-ended interviews would be beneficial.

- This study information is collected from a small New Zealand agriculture university Lincoln University- and therefore the results of this study may be used for recommendation at similar institutions.

- The study will only focus on academic staff at Lincoln University. Further studies to examine users' library seeking and using behaviour with different users groups such as students or visitors would be beneficial.

- The study imposes some research questions with a time period (within the last six months). This ensures that only recent behaviour is considered. The results of these questions could be applied to speculate on future use because of the rapidity of technological changes. 


\section{Literature Review}

\subsection{The Root of Information-seeking Behaviours}

The root of Information-seeking behaviour has been studied since the 1900 s. Most of these original studies focused commonly on how people use sources and channels to fulfil their information needs. Tibbo (2004) pointed out that the initial study of how information is used and not used in a library was conducted by Charles Eliot in 1902. In 1916, the first information-seeking study was conducted by Ayres and McKinnies on Cleveland public libraries (Case, 2007, p. 238).

In 1948, the concept of information-seeking behaviours was introduced the Royal Society Conference. Information-seeking behaviours were viewed indirectly at that time because it was shown that there was a concern about how people used libraries to obtain their work information, especially in science and technology fields (T. D. Wilson, 2000). Davis and Bailey (1964) pointed out most of the studies around the 1950s were about how people use their library services, such as: use of books, journals, handbooks, how many reference question were asked, and so on. In the 1950s, it was a significant period for information-seeking because information-seeking has been studied since then and the initial study was about specific subject users' behaviours (Case, 2002).

From the 1960s to the 1970s, there were many studies about how scientists and researchers gathered and used information in their research work and most of users' studies about library collection evaluation (Broadus, 1977; Tagliacozzo \& Kochen, 1970) An important study was conducted by Penelope Earle and Brian Vickery (Earle \& Vickery, 1969) in 1969 on how literature was used by social science in UK. The study used the Dewey classification method to assign subjects and found that researchers used the sources not just from the same field studies but as well as studies from other subjects. For example, there were about $42 \%$ of the respondents who indicated that they have used citations from outside of their field. This remarkable study covers most science and technology subjects and it was an important study based on users' preferences in using information. This study encouraged other researchers to do more studies on this topic of users. In succeeding years, there were other outstanding studies conducted on the information needs of researchers in both natural sciences and social sciences - for example, Garvey's (1979) work on how librarians, 
scientists, engineers and students use information within their libraries, which pointed out that in scientific community, most users obtain information by inter-personal communication.

From 1980 onwards, there was a big movement of information-seeking studies from a "system-centred" approach to a "person-centred" approach (Courtright, 2007). Research focused more on how people interact with information, so the understanding of the users' information habits and characters helped libraries to design suitable systems and services rather than evaluate the library system and study how the services were used. King, McDonald and Roderer (1981) have shown that there were different ways of reading an article in different science fields. The study pointed out users from most fields spent 30 to 70 minutes per reading but users from mathematic subject spent longer on reading an article, taking roughly about 225 minutes. There are also some studies about how users' background knowledge and experiences can impact their preferences in information. Patrick Wilson (1983) developed the "cognitive authority" theory and the key characteristics of cognitive authority. He pointed out information-seeking behaviours come from users' knowledge, experiences and can be referred to as second -hand knowledge. Wilson's conceptualisation of cognitive authority provides numerous implications for late studies on information behaviour in digital world. In the mid of mid 1980s, Dervin and Nilan (1986) began research that focused on how users carry out their information seeking and what their problems are in seeking information. The study is a call for a change from a "systemcatered" approach to a "person- centred" research approach. The study showed the limited scope of library circulation studies about the library system. It is important to understanding the nature of human behaviours because "system solutions" were not the only way to resolve the problems in information-seeking.

In the late 1980s, Ellis $(1987,1989)$ established an information-seeking model of users. Ellis' used observation method to study how academic staff getting information. His studies have covered a number of scientific subjects: social sciences, physical sciences and engineering sciences. His study has shown that the needs of users from different subject have direct effects on information seeking behaviours. It may require different information services and systems. However, the results from Ellis' studies showed that there are similarities in the information-seeking strategies of individuals or groups among the subjects. The study identified the six common patterns including starting, changing, browsing, differentiating, 
monitoring and extracting. Ellis' model was one of the first models of users' information seeking behaviour studies and it has pointed out that researchers' information behaviours can be analysed in different ways and it also defines some problems in information-seeking that researchers faced. Ellis' model is important because it has been used in many later studies and with many groups of users.

From 1990, there were more studies on how to design suitable systems and services by understanding the academics' research behaviours, so user studies have become information-seeking studies since 1990. Kuhlthau (1991) presents a model of the stages of information-seeking behaviour. The study described users' feelings, thoughts, actions and their need for the information at the beginning of the information seeking stage. Ellis did more studies in document retrieval systems (D. Ellis, Cox, \& Hall, 1993). The study confirmed that there were no crucial differences in the information-seeking patterns for physical and social scientists. It also showed that the information activity can be defined into the six steps model in all disciplines. Ellis and Haugan (1997) also confirmed that academic researchers have similar patterns in information-seeking; the major characteristics can be identified by eight characteristics, which are surveying, chaining, monitoring, browsing, distinguishing, filtering, extracting and ending. Wilson (1999) developed a nested model identifying three research areas, which are information behaviour, information-seeking behaviour, and information-seeking behaviour. He discussed the relationship among them and pointed out that both Kuhlthau's stages and Ellis characteristics can be related to this model. It is a problem-solving model. He stated that, in general, information behaviours are impacted by the channels of the information retrieval system.

\subsection{Disciplines and Information-seeking Behaviours}

A number of studies have been done on information-seeking behaviours by disciplines. Many studies have indicated that electronic content and journal articles are the most preferable information sources in all subject disciplines (Friedlander, 2003; Tenopir \& King, 2001, 2002; Tenopir, King, \& Bush, 2004; Tenopir, King, Montgomery, \& Aerni, 2003).

Belefant-Miller and King (2000) conducted a study on the reading behaviours of the science faculty and the differences between science and non-science. This study claimed that both the science and non-science faculties of academics have similar reading steps in research, which are finding, getting, reading, and using a document. However, they also have different 
reading purposes, and attitudes towards print and electronic information. Users from the science faculty are reading the key points of the article but others focus on the idea of the reading. Non-science users are reading three times fewer articles from the same journal than science users. The study indicated that science users are more likely to use networking systems to gain information than non-scientists - for example, science users spent 2.4 hours per week on email while non-science users only spent 2.0 hours a week. Nevertheless, email systems were highly used by both scientists and non-scientists in gaining information. The study also asked whether users like to read articles on screen; the results showed that one in seven science users prefer reading articles in a paper format rather than electronic. Science and non-science users both preferred the print version articles rather than the online version because reading a paper format is more comfortable than electronic, and the quality of graphic and data information is better.

Tenopir and King (Tenopir \& King, 2001) pointed out that users from medical groups relied more heavily on journal articles than users from other disciplines; on average, they read nearly twice as many articles a year as social science researchers. Information gathering in different fields has different forms of information searching strategies.

Tenopir et al. (2003) pointed out a study comparing how faculty and staff use journal articles for their teaching and research. The study showed that scientists used more electronic journals than humanists or those in the social sciences. Tenopir and King (2002) stated engineers have different information gathering habits - for example: engineers do not read as many articles as scientists per year but they spend more time on reading each article. Tenopir, King, Spencer and Wu (2009) did a study on how academic staff use scholarly articles. The study highlighted that academic staff from different disciplines have different reading patterns. Engineering academic staff spend a longer time on each article to get the latest information. They also read more than users from other subjects in getting information for research. Medical academic staff read more than users from other subject to keep up-to-date in their field. There are also other factors that affect the reading patterns, such as age, work responsibilities productivity of the reader and so on but the disciplines play an important role in distinct academics' reading habits. Korobili, Malliari and Zapounidou (2011) surveyed all graduates of the faculty of philosophy and the faculty of engineering to study whether the discipline is the most important factor affecting information seeking behaviours or not. The study indicated that discipline was not the only 
important issue affecting information seeking behaviours and both users from the philosophy and the engineering faculties had very similar information seeking behaviours as they preferred fast search results.

\subsection{Academics' Information-seeking Behaviours}

The information behaviour research has been conducted in various forms in higher education. Some studies focused on the use of internet sources and services, the use of search engines, and the search strategies of search engines (Griffiths \& Brophy, 2005; Jamali \& Asadi, 2010; Nicholas, Williams, Rowlands, \& Jamali, 2010). Other studies focused on information-seeking behaviours in different disciplines and information-seeking in different occupational groups (Engel, Robbins, \& Kulp, 2011; Niu et al., 2010; Wallis, 2006). Most of these studies indicated that nowadays information technologies offered users a range of points to access information, including: computers, the internet, online social networks, smart phones, online learning tools, digital libraries, databases and so on. These technologies have played a significant role in higher education and have impacted on users' information seeking behaviours (Rice-Livey \& Racine, 1997). Marchionini (1995) discussed information seeking and the changing environment. He pointed out that the user's primary way of gathering information is simply affected by the environment. The electronic environment has influenced users in information seeking, especially the interaction between the computers and users. Users scan electronic resources rapidly and continually until the information need is satisfied. This process of information-seeking in a digital environment is leading to new information-seeking strategies and behaviours.

\subsubsection{Source preferences}

Academics rely on the information sources from their own networking communication. Jamali and Nicholas (2008) surveyed 114 people, including PhD students and staff from the Department of Physics and Astronomy at University College in London. They found that academic status plays an important role in shaping users' information-seeking behaviours. They recognised that those with higher academic status, such as professors, relied more on oral and interpersonal communication such as conferences for keeping up-to-date, while PhD students were more likely to use other services such as advice and guidance from teachers or librarians, browsing electronic journals and e-print archives. 
Nicholas, Huntington, Jamali, Rowlands and Fieldhouse (2009) investigated the differences between students and other academic users' information-seeking behaviour in the digital world in the UK. The study provides clear information on how academic users seek their information in the digital world. The data was based on computer log data of 4240 transactions between October and December 2007 from two online journal engines, Blackwell Synergy and OhioLINK, and one e-Book library called Oxford Scholarship online. The study has found that:

- Staff tended to read more abstracts than students.

- Staff read abstracts and articles much faster than students.

- There were fewer staff users on the internet during weekends.

- Digital resources were mostly used by students.

- Technical issues caused information access problems

- Most users used the library web as a bridge to access scholarly databases.

Nicholas et al. (Nicholas et al., 2010) conducted a study of researchers' e-journal use and information-seeking behaviour in the UK and compared it with the previous study which used a deep log analysis to find the usage and information seeking behaviour of researchers in relations to databases. The study used a quantitative research method and the data was collected from interviews, questionnaires and observations. The study covered six subjects at nine major research institutions with 1371 people sampled. It has better and deeper analytical results compared with the previous study where the data was collected from recorded usage on the computer. This study has confirmed that the internet is the first choice for researchers' information-seeking nowadays and researchers from all disciplines preferred to use gateway search engines, such as Google Scholar and Google.

Debra Engel et al. (2011) carried out a study of information-seeking behaviour of engineering faculties at twenty academic institutions across the United States. The study showed that most academics obtain information from a range of people who have close working relationships with them. They gained information from conferences, meeting their colleagues and students and friends from similar organisations. 


\subsubsection{Tools and channels}

Thompson (1999) did a study about issues in using the latest technologies in higher education. The study argued that academics often do not motivate "...investment of their time in learning to use new technologies effectively will provide long-term gains, most especially in the current climate of competing priorities and demanding deadlines" (p.159).

Weber and Flatley (2006) reported that most faculties preferred remote access. Ally (2001) conducted a study on researchers' perspectives on using electronic resources in relation to scholarly communication. The study found out that the internet and emails are commonlyused tools in teaching and research. It also found that researchers are increasingly gaining benefits from using electronic resources due to the conveniences. Online information also brought people closer in their work. For example, the traditional research process can be done in electronic form, such as publication journals, e-Conferences, online job advertisements, email discussions and calls for papers via internet and so on.

Haglud and Olsson (2008) strengthened previous research on academics' information behaviour. They found that researchers were confident with their information-seeking and they relied heavily on gateway electronic information such as Google, which most researchers used for seeking information. Jamali and Asadi (2010) also claimed that Google has become one of the popular search engines in higher education and "...academics are also heavy users of Google for research purposes" (Jamali \& Asadi, 2010).

Ji-Hong (2010) conducted a study on comparing the social networking usage of students and faculty members. The study used semi-structured and open-ended interviews to collect data, including from undergraduates, graduates and faculty members at Yonsei University in Seoul, South Korea. The study showed that faculty members are using much less SNS (social networking sites) and they have much less interest in using the SNS compared with students. In the interviews, there were no faculty members actively using SNS and no professors indicated that they were using SNS. The studies also indicated the reasons why fewer faculty members are using SNS are because they considered their privacy issues and they usually do not have time to do something that does not benefit them directly. 


\subsubsection{Accessing}

Kuruppu and Gruber (2006) interviewed groups of academic scholars to study their information-seeking behaviours in the agricultural and biological sciences via a survey at the University of Arkansas. The study showed electronic resources are becoming the core resources for most scholars and faculty members. However, they were not familiar with search engines and they lacked the knowledge and skills to find the information needed for research, teaching and learning. The study also suggested that the library needed to have short and clear sessions on improving users' skills in finding information both online and offline.

Information Research Network from the UK conducted a study on researcher's behaviour in 2009. The study reported that researchers have difficulty in accessing the information they need (Overcoming Barriers: access to research information, 2009). The difficulties are restrictions on accessing e-content from other institutions and libraries, the accessibility of public and private sector information, the awareness of their own library services and tools, technical issues, lack of information-seeking skills etc. Swigon (2011) also pointed out that it is normal for users to have problems in information-seeking. According to her study, about $80 \%$ of academic users face problems in the information seeking process and most of those issues were associated with their library.

\subsection{Use of the Library}

Today, many or most teaching and research resources can be obtained in digital form and, as a result, users are changing their habits as they do not need to come into the physical library for getting information (Hiller, 2002). The physical library becomes a student-dominated place and the usage of the physical library by academics has declined since the mid-1990s (Martell, 2008).

\subsubsection{Library visiting}

In 2002, the University of Washington Libraries did a study on how academics were using their university library (Hiller, 2002). The study was conducted by surveys from 1992 to 2001. The study found that academies and graduate students were visiting the library less compared to undergraduate students. Academics spent more time on remote accessing 
from their desktop. Statistics on the use of library services reported by the American Library Association show that library usage in the UK has "...declined $21 \%$ and circulation has fallen by 35\% from 1994 to 2004" (Analyst Claims UK Libraries in Decline; CILIP Begs to Differ, 2004). This report also indicated that by 2020 libraries within the UK could be unused.

Hemminger, Lu, Vaughan and Adams (2007) conducted a study on the information-seeking behaviour of academic scientists that revealed that researchers preferred to obtain information via the internet because it was the easiest and fastest way. The study also revealed that "...the most common reasons for researchers visiting the library were for other services such as photocopying, teaching, catching up with friends and dropping off print materials". Fewer visits and contacts in the library made it more difficult for academics to keep up with the latest resources and services in the library (Watson, 2010). It is also more difficult for librarians to have a close working relationship with academics.

Haines, Light, O'Malley and Delwiche (2010) did a study on science researchers' informationseeking behaviour in relation to their library services. The study covered nine science faculty members and was based on a qualitative research method with a "semi-structured interview". This study discovered users do not use library services much for their teaching and research, because users are convinced their own ways of information seeking are better.

\subsubsection{Use of services}

Studies conducted among academics and researchers have shown that most of them are inadequate in using libraries. Don (2006) conducted a comparison study of students and faculty staff in using their academic libraries. He highlighted that almost half of the faculty members in the survey reported that they usually cannot print journal in their university libraries, and they have to go thought other university libraries.

Kinnucan (1994) compared document delivery and interlibrary loans used by faculty and graduates. He found that faulty members were willing to pay interlibrary loans and for commercial document delivery services if it sped up access to the information they needed. The increasing number of users obtaining electronic resources on the internet also increases the number of problems users have in accessing the resources. With these issues, librarians should take it as an opportunity to prioritise their services according to researchers' needs and that researchers can make the most effective use of library services. Primary Research 
Group (2009) did a survey on academic staff from more than 550 higher education faculties in the United States and Canada about the use of the inter-loan services in their institution library. The results showed that the inter-loan service has very high usage, as $90 \%$ professors and more than $80 \%$ of faculty used loan services in their libraries.

Dickenson (2006) conducted a report on academics' teaching and students' learning by using their academic library in Colorado. The report surveyed faculty members and students from nine Colorado higher education institutions. The study reported that $84 \%$ of responding academics agreed that they are happy with the accessing of electronic resources via their libraries. However, less than half of responding academics indicated that they cannot find the books they need at their library and nearly half of academics expressed they have difficulties in finding appropriate print journals. The study also indicated that most users used library services. There were $83 \%$ of responding academics using electronic resources and $87 \%$ of respondents using print resources from their library. Inter-loan services were highly used by academics, as $75 \%$ of responded academics reported they used it. In terms of how library services are used for the academics' teaching, the report showed that $61 \%$ of responding academics agreed that libraries had helped students in finding information for their study and just over half of the academics indicated their library had assisted students by providing course information. More than three out of every five academics used library instructions for their teaching.

\subsubsection{Use of search engines}

Some studies have indicated that Google Scholar has become a popular and easy tool to use for researchers, which is a sign of competition to the academic library resources (Badke, 2009; K. A. Hartman, \& Laura, B. M. , 2008; K. A. Hartman \& Laura, 2008; Sennyey, Ross, \& Mills, 2009).

The Research Information Network and the Consortium of Research Libraries (2007) did a report on how researchers have been making use of their libraries services in the UK. The report used the qualitative method and included a series of focus group discussions and interviews. The data was collected from 2250 researchers and 300 librarians. The report showed that as technology develops and information resources online become more available, researchers make more use of web search engines. Google has become the most- 
used tool for researchers to start their research, rather than university library websites. The report also highlighted the researcher's main frustration is they have difficulties in accessing online resources. Researchers make more use of the online search engines as the internet provides the fastest and easiest way to locate information.

A case study analysed by Brophy and Bawden (2005) compared the performance of Google and library databases in terms of their coverage, unique records, precision, quality and accessibility of results in two academic libraries in the UK. The study highlighted that Google has better accessibility to the resources, and that library search engines have better quality of results. The finding also shows that Google's coverage in some field is quite good and huge numbers of scholars' articles can be found.

In Hartman and Laura's (2008) article on the current view of the use of Google Scholar by academics, it was debated about whether or not Google Scholar was a good approach to integrated Google Scholar into academic library websites. The study examined 113 ARL academic intuitions and found that the number using Google Scholar path doubled after Google Scholar appeared on library websites from 2005 to 2007. It has been suggested that an implication of further integration of Google Scholar into library websites will be useful for users.

Sennyey et al. (Sennyey et al., 2009) reviewed future academic libraries in a virtual world. They argued that the library is a place providing information services to users where the physical place, collection and staff are working together but it is not the same as in the digital environment. The study worried that as Google becomes the primary search method for most users, and the development of scholarly literature in Google makes researchers work process much easier, the increasing use of online resources may remove the library itself as a place, collection and institution in the future. 


\subsubsection{Satisfaction}

Martensen and Gronholdt (2003) investigated a measurement and management system to improve library users "perceived quality, satisfaction and loyalty". The study reviewed a variety of literature and surveyed focus groups to identify the key elements for library service quality which were: "electronic resources, collections of printed publications, other library services, technical facilities, library environment and human side of user service". Kottler (2006) pointed out that improving customer satisfaction is the least moneyorientated tool for improving a company's long term profit.

The majority of academic research has shown academic staff are satisfied with their institution library. The Primary Research Group (2009) conducted a study to gain academics' opinions and their satisfaction with their institution library. The study surveyed more than 550 higher education academic staff in the United States and Canada. The result of the study highlighted that less than $20 \%$ of academics were unsatisfied with the help from library staff when they needed it, and almost half of the faculty members from the US were very happy with the library inter-loan services. $30.77 \%$ of academics from Canada were highly satisfied with inter-loan services. However, almost $70 \%$ of faculty were not satisfied with the comfort level of the physical library building and almost $85 \%$ of the responses reported that they could not find materials for personal scholarly searches in their institution library.

Adeniran (2011) conducted a research on assessment of the library services quality based on academics and students satisfaction levels. The study applied a questionnaire survey to collect data from a total of 187 academic staff and students at Redeemer's University. The results showed that, overall, users were satisfied with the services of the library, with $58.3 \%$ of respondents agreeing that library staff provided relevant and personalized services and 74.3\% of respondents reporting that the library staff were efficient with their duties.

\subsection{Conclusion}

There has been a long history of research on information-seeking behaviours. The studies began in 1900 and are still a popular study even today. Understanding academic members' information-seeking behaviour is very important information for academic libraries. It is clear that new information technology will bring users into new information-seeking patterns. Academics rely on more digital resources than the collection in the physical library, 
which creates a new pattern of academics' use of their institution's libraries. Additionally, as academics are leading higher education, most of them are confident and have their own ways of information-seeking. Libraries need to identify academics' behaviours in finding information in order to improve their services. The discipline is also the key factor that influences the academics' seeking behaviours.

Choy (2011) states that librarians need to keep up with the latest information technologies in order to provide more focused and better services in the digital world. The question remains, without having understood the key user behaviours in all disciplines and their relation to use of their library, how can librarians identify the most useful tools and services for their users? On the other hand, the unique disciplines at Lincoln University, advances in technology, and economic pressures, create a new environment, leading the library into challenges and opportunities. The way to measure the challenges, opportunities and changes of the library is to conduct user studies which investigate user needs, expectations and satisfaction. There have been no prior studies on how academics obtain information and use Lincoln University Library system and services. This study will be a good exercise to obtain the insights into information-seeking behaviours of academic staff at Lincoln University. 


\section{Methodology}

\subsection{Population}

This study will be conducted on all the academic staff that are currently listed on the Lincoln University Microsoft Outlook Email system. There are three main faculties: the Faculty of Agriculture and Life Sciences, the Faculty of Commerce and the Faculty of Environment, Society and Design.

Lincoln University was chosen for several reasons. First of all, I have been studying and working at Lincoln University for nearly nine years and it has been always my interest to find out how academic staff are getting information by using Lincoln University Library. Secondly, it is practical to invite all the academic staff to be part of this research. Lincoln University has three academic faculties and two divisions deliver teaching and research. However, one of the divisions, Foundation Studies and English Language, does not involve research work. The second division, Telford, just joined Lincoln University in 2011 and the location of Telford division is not on campus, so this research will not be including either of them. Therefore, the three main faculties will be selected and it will well represent the different disciplines in this study. Lastly, the Lincoln University Microsoft Outlook email system is the only internal email system that is used for staff communication and the system has all the currently working academic staff's email addresses. The use of the email system will be the most suitable and effective way to reach and target potential participants. According to the internal email system - Microsoft Outlook Email - there are about 251 academic staff from these three faculties. The details are listed below:

\section{Table 1, Research population}

\begin{tabular}{|ll|}
\hline Name of Faculty & Number of Staff \\
\hline Agriculture and Life Sciences & 88 \\
\hline Commence & 74 \\
\hline Faculty of Society and Design & 89 \\
\hline Total & 251 \\
\hline
\end{tabular}




\subsection{Method}

According to Kawatra (1992), the user's studies are subject to a variety of research methods, from a quantitative approach, or a qualitative approach, to a combination of both approaches. There are also extensive and intensive methods which have been applied in studies of library users. According to Wildemuth (2003) the elements to choose the most suitable method for study are research objectives, questions, together with other factors such as the availability of the resource.

Kawatra (1992) discussed that the main difference between quantitative and qualitative approaches is that "... qualitative data involves words which pursue the understating of an event or behaviours from participants" and quantitative data involves numbers and statistical description to explain objectives. Many different techniques have been used to study people's use of libraries. Kawatra (1992) outlined four ways of data collection:

Surveying: this is a tool that gains answers directly from users about their behaviour, attributes, values, conditions and/or preferences. Surveying can be done online and it is easy to design and implement with minimal resources. However, surveying has limitations because it is the most obtrusive method.

Observation: This is direct communication to observe users' behaviour but it needs to be done when people are available. It requires that the researcher be there with participants in the situation. It can provide useful insights into a user's behaviour.

Record analysis: This is a method that collects data from previous communications, such as written papers, correspondence and statistics, and then use the recorded data to analyse.

Experimentation: Introduce an element to a group of users. Witness their behaviour and results and compare the group with another where the element was not introduced.

Kawatra (1992) further discussed four elements to choose the right method for users studies. Firstly, the method must be suitable for studying the problems. Secondly, the method must be within available resources. Thirdly, the method will be used by potential participants. Lastly, the method can produce the data that researchers need.

After weighing the advantages and disadvantages of the various methods above, Equestionnaire surveying has been chosen as the main research instrument for data 
collection for this study. An email will be sent to all the current working academic staff with a link to the questionnaire. The quantitative data will be collected through the questionnaire.

A questionnaire survey is the most cost-effective and the least intrusive method when compared to other methods (Bryman, 2012, p. 676). This is especially true for studies involving academic staff because they are usually short of time and busy with teaching and research. It will be hard to access them for face-to-face interviews. The online questionnaire survey will be the most suitable method to collect data as it is convenient and time-saving for both academics, and for researchers who are doing a degree. The questionnaire survey is also easy to analyse because data entry and tabulation will be done with an online survey programme.

However, an online survey has lower response rates in comparison with other traditional methods of data collection (Bryman, 2012, p. 670; Porter \& Whitcomb, 2003). Potential participants may delete the email by mistake or they may begin to complete the survey but for some reason they do not finish the survey. To avoid non-response or low response rates, this study has a few strategies:

- Write a good covering letter

- Keep the questions focused, and have the survey as short as possible while still covering the research questions

- Academics will have two weeks to respond and a reminder email will be sent one week before the closing.

- Provide an incentive. Participants will have the chance to win a prize of $\$ 40$ gift card.

\subsection{Research Tools}

This study will use the licensed online survey software called Qualtrics from Victoria University of Wellington. The survey will be sent out via email from the researcher's student email account at Victoria University of Wellington.

Steps and Tools:

- Academic staff's email addresses were generated from the Lincoln University Microsoft Outlook email system. 
- The Victoria University of Wellington licensed online survey program called Qualtrics will be used for creating the survey.

- The designed online survey was sent out via Victoria University student email.

- Qualtrics survey software was used collect the survey responses, which automatically inputted data into a spreadsheet.

- Microsoft Excel spreadsheet will be used to generate data, charts and tables.

\subsection{Survey}

There are 19 questions on the survey, which takes about 20 minutes to answer. The survey is largely designed by a fixed-response method, such as yes and no, choices, and rating scales questions. It is quick to answer and responses are easy to graph for data analysis.

The survey questions were designed to determine the academics' behaviours in seeking information at Lincoln University Library:

- Demographic profile: the respondents are required to state their major, position and academic experiences.

- Information behaviours: the respondents are required to indicate their preferred format, methods in information-seeking and the tools and places used for information-seeking. Respondents also were asked to identify their most-used methods in keeping up-to-date in their field and the issues they have in getting information.

- Use of Lincoln University Library, such as websites, services and collection: The respondents were asked to indicate the reasons for visiting the library, whether they use the Lincoln University Library website to get information for teaching, how much time they are spending using the Lincoln University Library resources, and their satisfaction in accessing the library collection. 


\subsection{Data Analysis}

Data will be collected in early August 2012. Qualitative data will be collected from respondents to the survey. The online survey program will turn the data into graphs to analyse.

The main analysis points will be

- Information-seeking behaivours

- What are the most-used devices, formats, methods, search engines and social networking tools?

-What are the similarities and differences among subjects in information seeking?

- How do academics keep up-to-date with their field?

- Problems that academics encounter in getting information?

- Library use

- How much do academics use their Lincoln University Library?

- How do academics use Lincoln University Library in teaching?

- Are academics satisfied with the library services and collections? 


\section{Data Results}

\subsection{Response Rate}

In total 49 out of 251 academic staff submitted an online survey with an effective response rate of $19 \%$ but not everybody answered all questions.

\subsection{Characteristics of Respondents}

Respondents were asked to identify themselves by faculty, academic status and academic working experiences. It is useful to see the characteristics of the respondents because the characteristics will support the discussion of academics' information-seeking behaviours and their use of Lincoln University Library.

Table 2, Distribution of the respondents by faculty

\begin{tabular}{|lcc|}
\hline Faculty & Response & $\%$ \\
\hline Agriculture and Life Sciences & 21 & 42.9 \\
\hline Environment, Society and Design & 20 & 40.8 \\
\hline Commerce & 8 & 16.3 \\
\hline Total & 49 & 100 \\
\hline
\end{tabular}

Table 3, Distribution of the respondents by academic status

\begin{tabular}{|lll|}
\hline Status & Response & $\%$ \\
\hline Professor & 4 & 8.2 \\
\hline Associate/Assistant Professor & 6 & 12.2 \\
\hline Senior Lecturer & 22 & 44.9 \\
\hline Lecturer & 10 & 20.4 \\
\hline Research Staff/Adjunct & 3 & 6.1 \\
\hline Other & 4 & 8.2 \\
\hline Total & 49 & 100 \\
\hline
\end{tabular}

The distribution of the respondents shows that there is a range of people who have participated in this study. The biggest proportion of respondents was senior lecturers (44.9\%). The smallest percentage of respondents was research staff (6.1\%). There were also four other kinds of staff who participated in the survey, such as tutors, curators and so on. 
Table 4, Distribution of the respondents by working as academics

\begin{tabular}{|c|c|c|}
\hline Background & Response & $\%$ \\
\hline Less than 5 years & 11 & 22.4 \\
\hline $5-10$ years & 14 & 28.5 \\
\hline $11-15$ years & 7 & 14.3 \\
\hline $16-20$ years & 4 & 8.2 \\
\hline $21-25$ years & 5 & 10.2 \\
\hline Over 25 years & 8 & 16.4 \\
\hline Total & 49 & 100 \\
\hline
\end{tabular}

The distribution of years that academics have been working as academics shows that of the 49 respondents to the survey, the highest number of respondents had 5-10 years professional experience, at $28.5 \%$ and the lowest number of respondents ( 8 or $16.4 \%$ ) had 16-20 years. 


\subsection{Information-seeking Questions}

\subsubsection{Time distribution - library resource}

Respondents were asked to indicate how much time they spent visiting the library in person compared with using the library services online.

Please indicate the time you spend using Lincoln University Library resources both at the library and accessing library resources remotely (total must equal $\mathbf{1 0 0 \% ) .}$

Chart 1, Time distribution in using Lincoln University Library resources

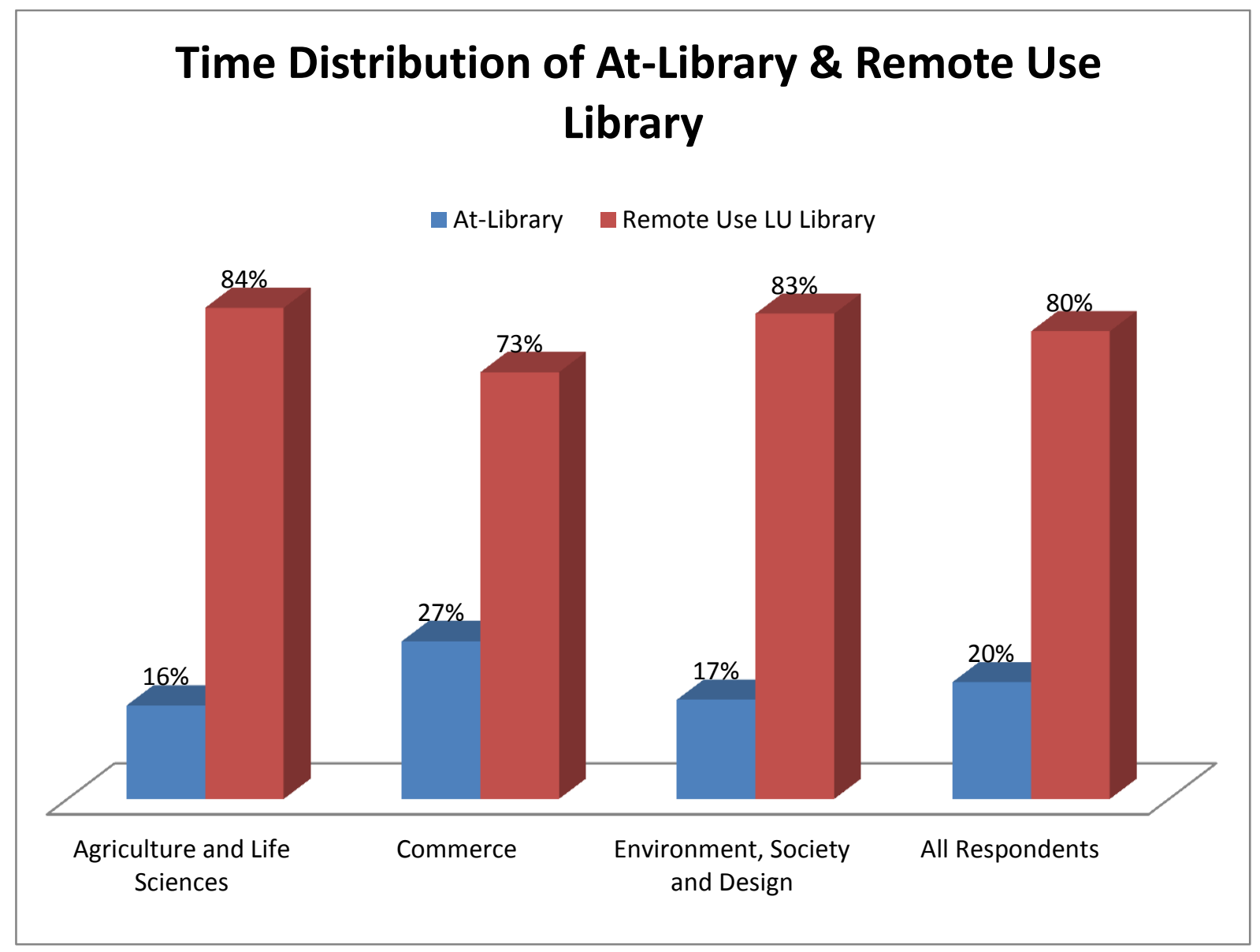

The figures above provide data about time distribution of the respondents in using Lincoln University Library resources. It shows all respondents have a very high use of the online Library resources. On average, respondents use most of their time (80\%) in accessing Lincoln University Library resources remotely compared with $20 \%$ of their time in accessing the Library physically. Respondents from Agriculture and Life Sciences (84\%) and Environment Society and Design (83\%) spend the longest times for using the library remotely and respondents from Commerce were the longest time users in the library, with $27 \%$. 
Please indicate why are you visiting Lincoln University Library in person?

Respondents were asked to indicate the reasons for visiting Lincoln University. Respondents were allowed to select more than one answer.

Chart 2, Reasons of onsite use of Lincoln University Library

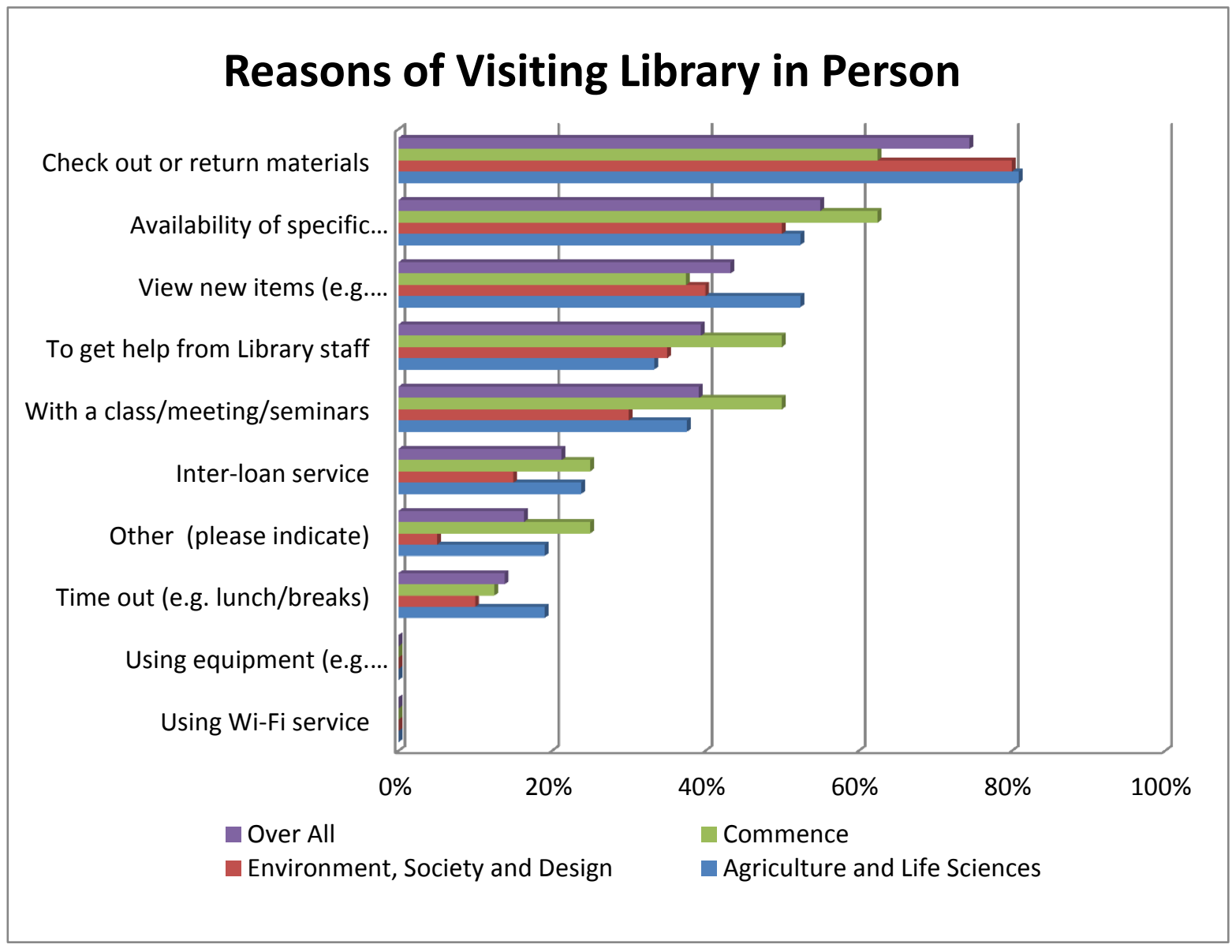

The figures above provide data about the reasons for academics visiting Lincoln University Library in person. The top three reasons for respondents visiting the library are checking out or returning materials (74\%), the availability of specific materials or information (55\%) and viewing new items (43\%). 39\% of academic staff indicated that they go to the library to get help from library staff and use the library as a place for classes, meetings and seminars. It seems that inter-loan services were not the main reason for respondents going to the library, only $22 \%$. Nobody goes to the library to use the equipment or Wi-Fi service. A small number of respondents (16\%) noted that they have other reasons to go to the library, such as the IT help desk located in the library, assisting students to find suitable material, and browsing.

The top three reasons for Agriculture and Life Sciences and Environment, Society and Design visiting library in person are the same, which are to check out or return materials, view new 
items and availability of specific materials or information, and viewing new items. In contrast, the main reasons for respondents from Commerce are the availability of specific materials or information (63\%), checking out or returning materials (63\%), with class/meeting/seminars (50\%) and getting help from Library staff (50\%).

Ultimately, a high proportion of respondents (74\%) do go to visit the physical library to check out and return materials.

\subsubsection{Time distribution - search engines}

Please indicate the time you spend using Lincoln University Library search engines and non-Lincoln University Library search engines (e.g. Google, Yahoo) to begin your information search (total must equal 100\%).

Respondents were asked to indicate how much time they spent using Lincoln University library search engines person compared with non-Lincoln University Library search engines.

Chart 3, Time distribution in using Lincoln University Library search engines and nonLincoln University Library search engines

\section{Time Distribution of Using Search Engines}

- LU Library search engines non-LU Library search engines

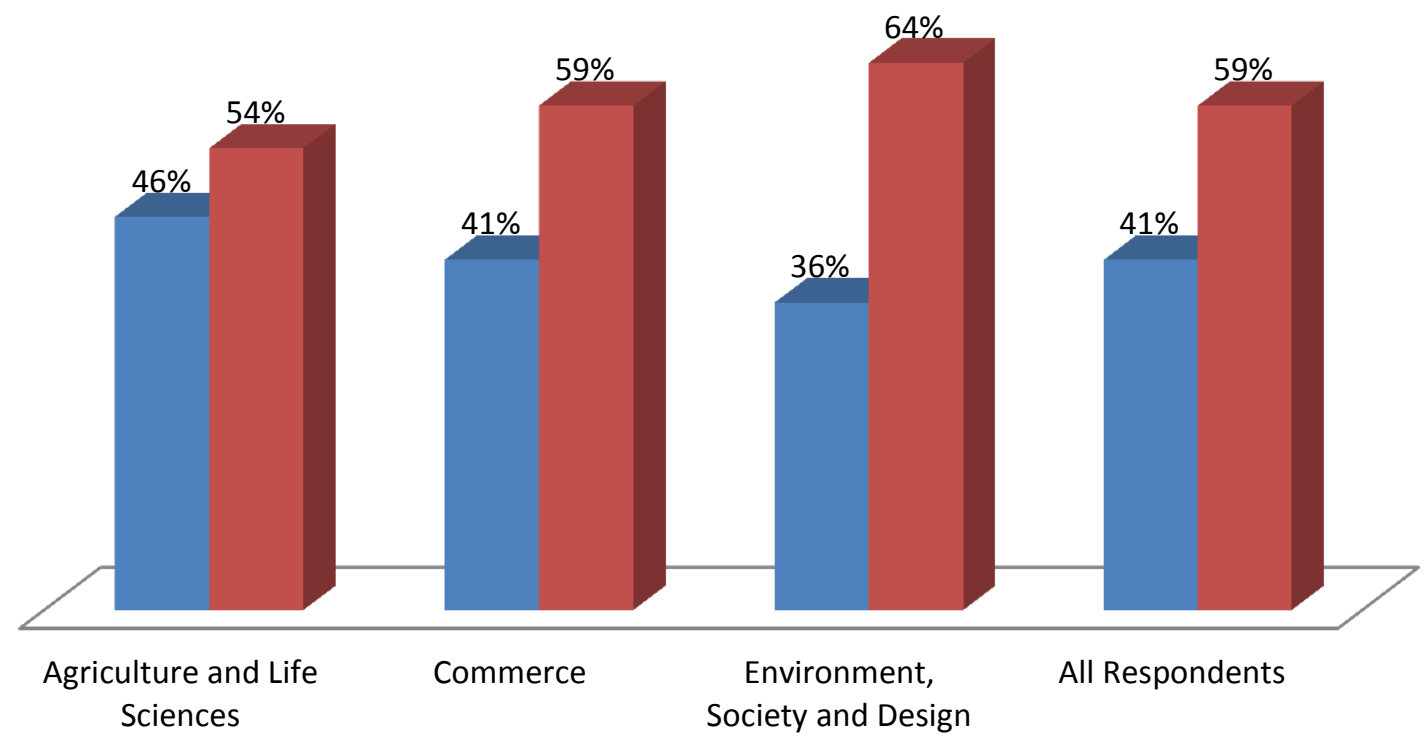

The above chart shows the time distribution of the respondents in using Search engines. On average, respondents use well over half of their time (59\%) to access non-Lincoln University 
Library search engines to begin their search, compared to $41 \%$ of their time using Lincoln University Library.

All respondents from each faculty spend slightly more time accessing non-Lincoln University Library search engines than search engines from Lincoln University Library to begin information search.

How often do you search other library catalogues (e.g. World Cat, public libraries, and other educational institutions) by using links provided by LTL (Library, Teaching and Learning) website?

Chart 4, Frequency of accessing other library catalogues via LTL (Library, Teaching and Learning) website

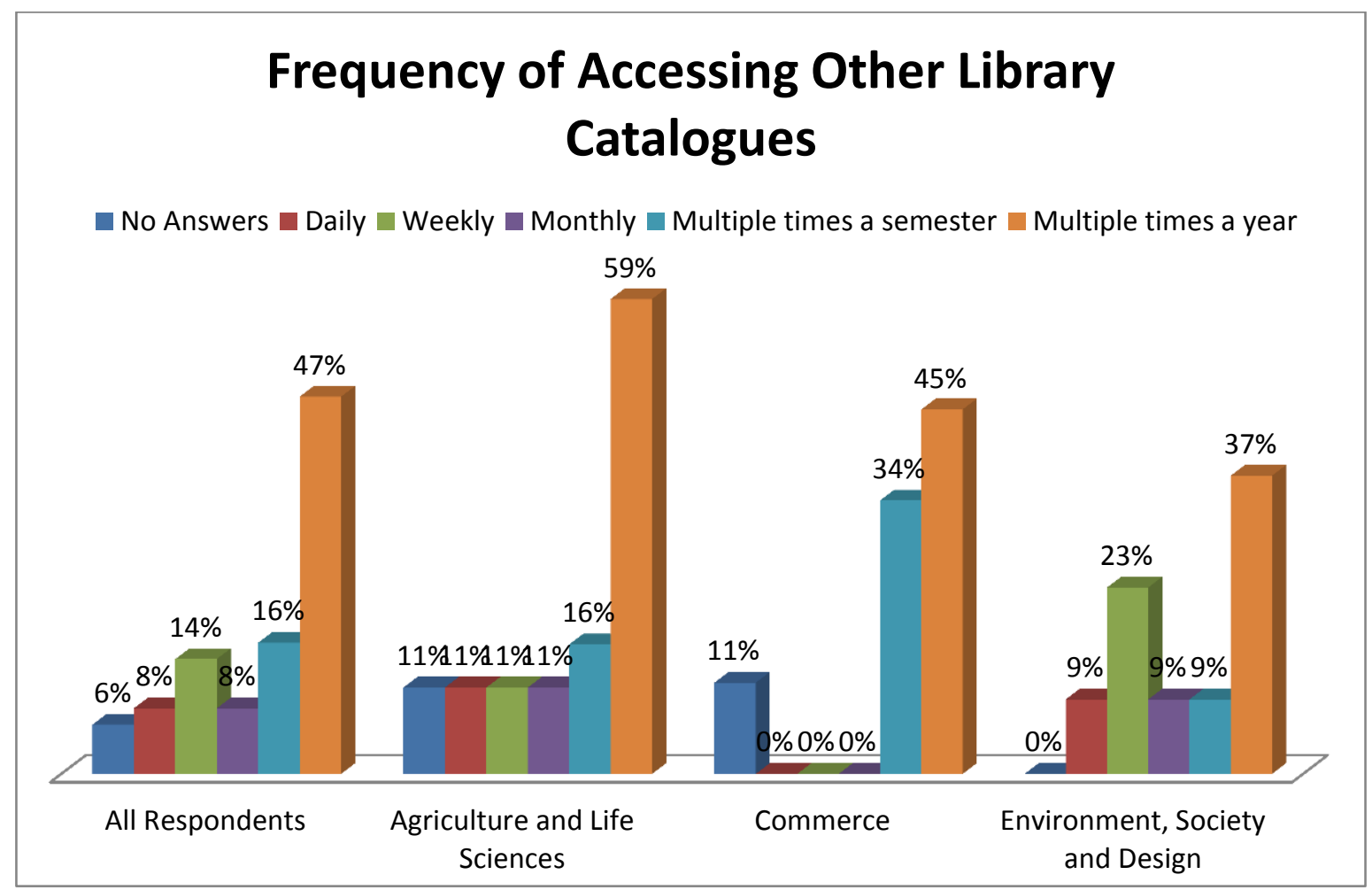

The above figures are about how often respondents use other library links provided by LTL website. The figures indicate that the majority of respondents often do not use other library catalogues via LTL website. Almost half of the respondents (47\%) use other library catalogues via LTL website multiple times a year. Only a very small of number of responding academics uses other library catalogues via LTL website daily (8\%), weekly (14\%) and monthly (8\%).

Respondents from Commerce had nobody use other library catalogues via LTL website daily and weekly. Additionally, respondents from Agriculture and Life Sciences and Environment, 
Society and Design had very low usage in accessing other library catalogues daily, weekly and monthly.

\subsubsection{Preference - format, device and method}

Respondents were asked to indicate their preference of format, device and method in information-seeking.

What format do you prefer to use in information-seeking?

Chart 5, Academics information seeking format preferences in format

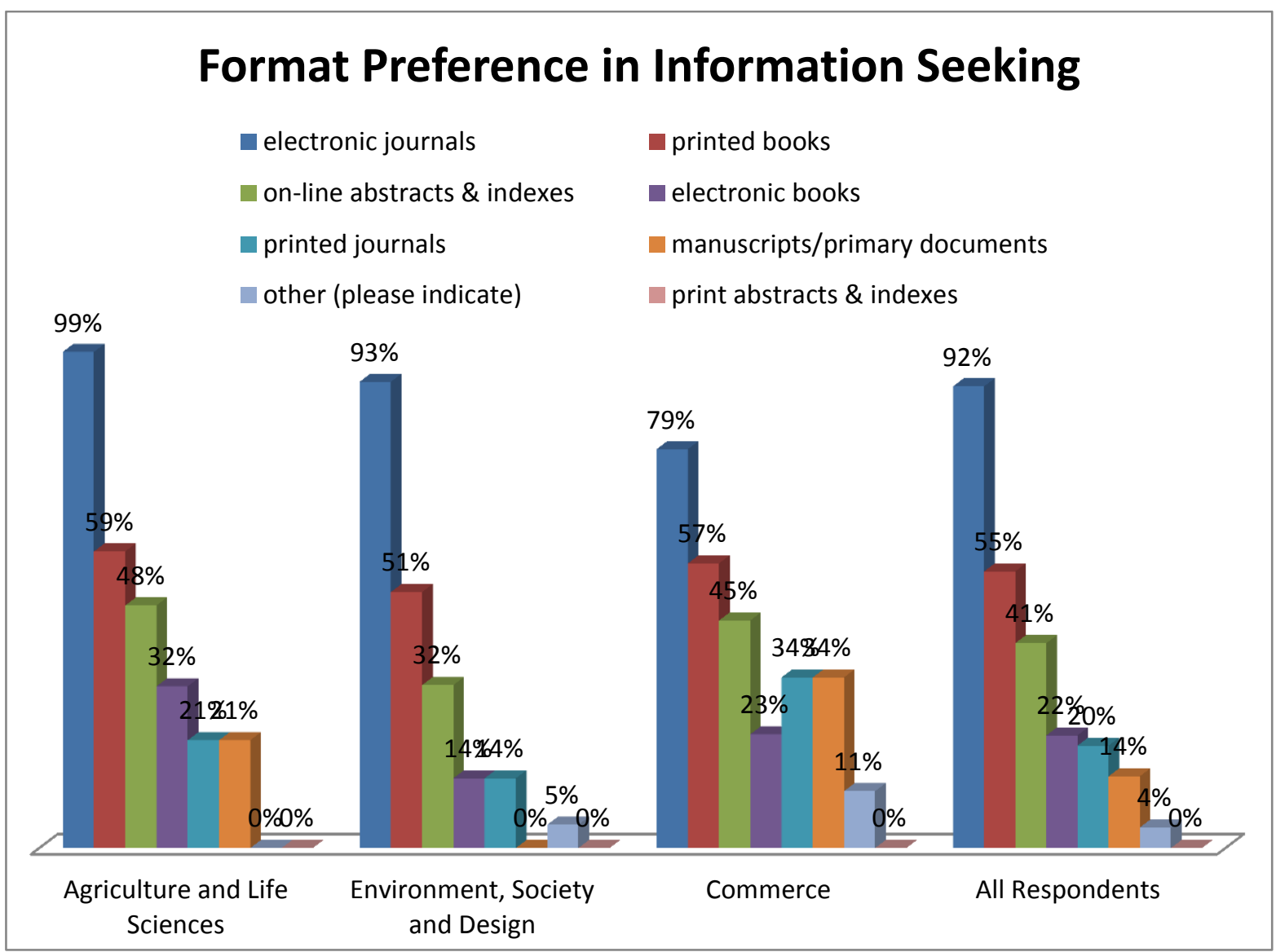

Overall, the figures above display clearly that most respondents prefer electronic journals (92\%). It seems that printed books are more popular than electronic books for academics. Over half of the respondents prefer printed books (55\%) while only a few respondents prefer electronic books (22\%). The third format preference in information-seeking was on-line abstracts and indexes (41\%). Very few respondents prefer information from manuscripts documents (4\%) and nobody likes print abstracts and indexes (0\%).

More respondents from Commerce academics prefer using printed journals (34\%) and manuscripts documents (34\%) than those in the Agriculture and Life Sciences and 
Environment, Society and Design. All respondents from Agriculture and Life Sciences prefer electronic journals, with $99 \%$ of respondents, but $79 \%$ of respondents from Commerce.

Please select devices you use most in accessing electronic resources?

Chart 6, Most-used devices in accessing electronic resources

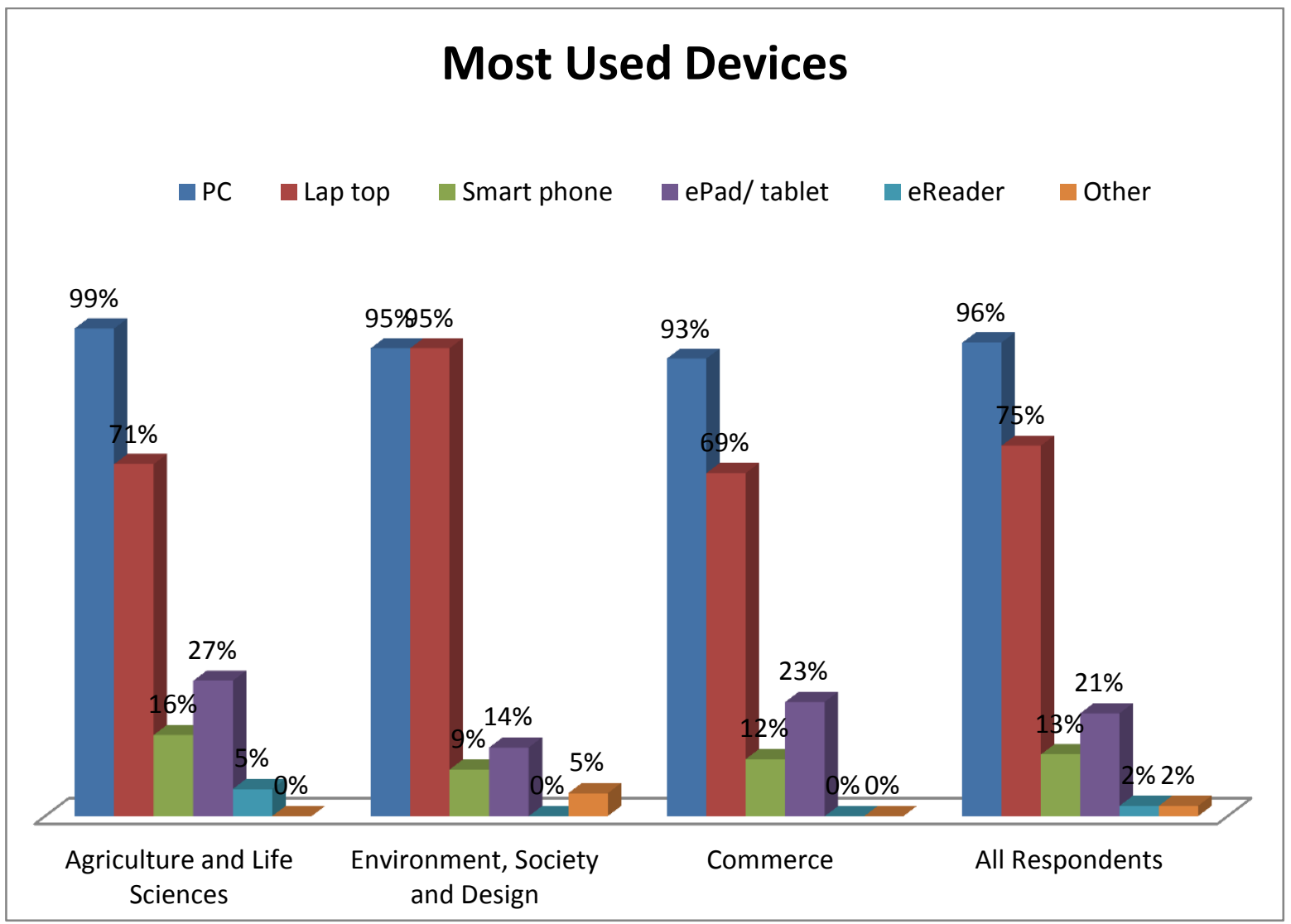

Not surprisingly, the most popular devices are PCs and laptops for respondents to access electronic information, with $96 \%$ using PCs, and $75 \%$ using laptops. Only a few respondents say they use tablets $(21 \%)$, smart phones $(13 \%)$, and eReaders $(2 \%)$. The highest percentage for using PCs and laptops for this response was reported by Agriculture and Life Sciences. The lowest percentage for using PCs and laptops for this response was reported by academics from Commerce.

It is interesting that nobody from Environment, Society and Design and Commerce indicated that eReaders are the most-used device in information-seeking. 
Please select 3 methods you have used most to obtain information in the last 6 months.

Chart 7, Three most-used methods to obtain information in the last six months by faculties

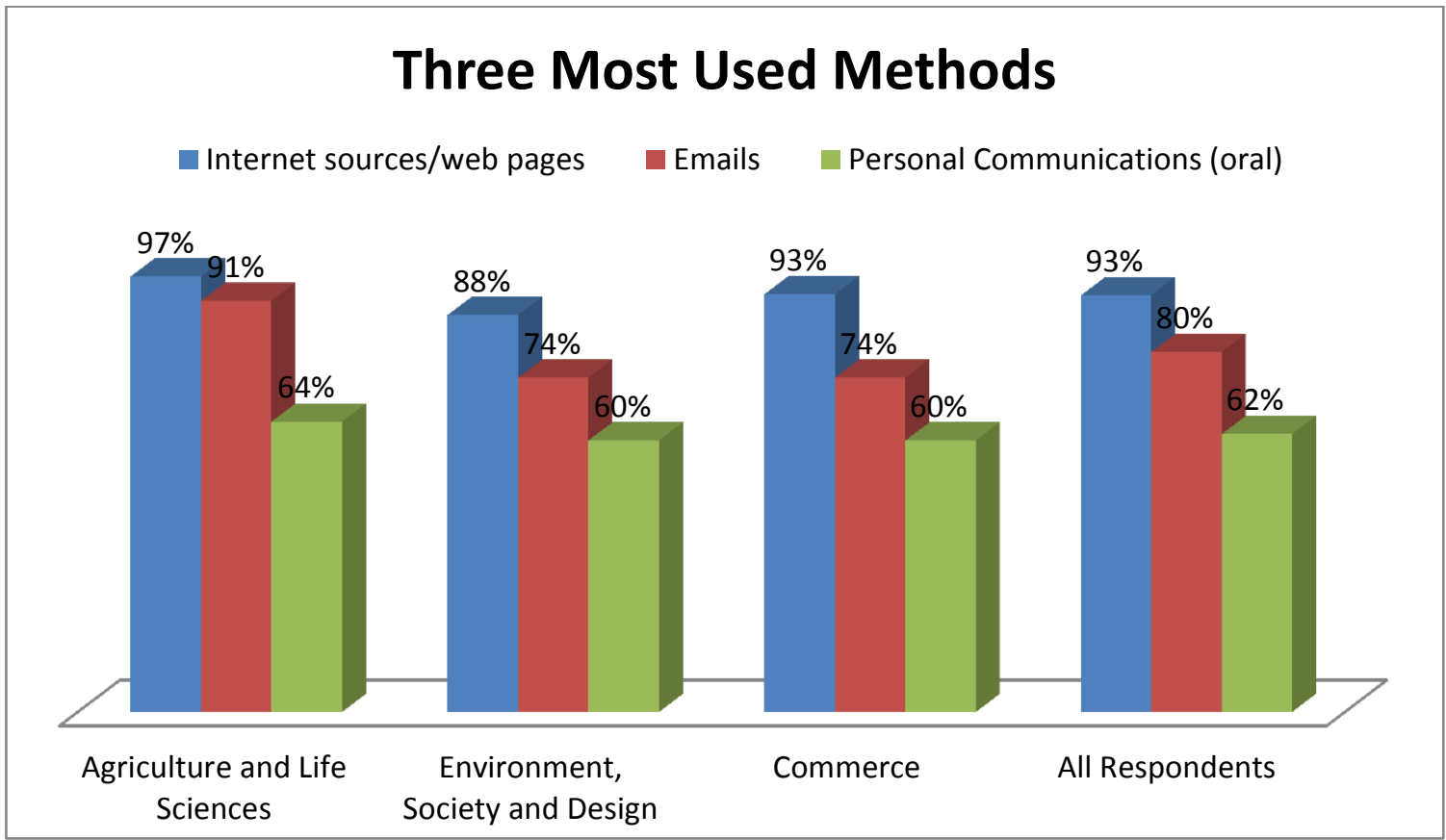

The figures above are about the top three methods academics have used in informationseeking in over the past six months. It clearly indicates that most respondents used internet sources (93\%), then emails (80\%) and lastly oral personal communication (62\%).

More respondents from Agriculture and Life Sciences (91\%) use emails than respondents from Environment, Society and Design (74\%) and Commerce (74\%).

Table 5, The least-used methods to obtain information in last six months

\begin{tabular}{|c|c|c|c|c|}
\hline Answer & $\begin{array}{l}\text { Agriculture and } \\
\text { Life Sciences }\end{array}$ & $\begin{array}{l}\text { Environment, Society } \\
\text { and Design }\end{array}$ & Commerce & $\begin{array}{l}\text { All } \\
\text { Respondents }\end{array}$ \\
\hline E-Meetings/Conferences & $27 \%$ & $14 \%$ & $14 \%$ & $18 \%$ \\
\hline Teleconferencing & $21 \%$ & $5 \%$ & $5 \%$ & $10 \%$ \\
\hline Other (please indicate) & $21 \%$ & $14 \%$ & $14 \%$ & $16 \%$ \\
\hline Radio broadcasts & $11 \%$ & $14 \%$ & $14 \%$ & $13 \%$ \\
\hline Letters through the post & $5 \%$ & $0 \%$ & $0 \%$ & $2 \%$ \\
\hline Fax & $0 \%$ & $0 \%$ & $0 \%$ & $0 \%$ \\
\hline
\end{tabular}

It is interesting to point out that only a few respondents indicated that they have used Emeeting/Conferences (18\%), teleconferencing $(10 \%)$ and almost nobody reported the use of letters through the post (2\%) or fax (0\%). 


\subsubsection{Keeping up-to-date}

Can you please select the 3 methods and resources you use most for keeping up-to-date in your field?

Table 6, Methods and resources for keeping up-to-date

\begin{tabular}{|c|c|c|c|c|}
\hline Answer & $\begin{array}{l}\text { Agriculture } \\
\text { and Life } \\
\text { Sciences }\end{array}$ & $\begin{array}{l}\text { Environment, } \\
\text { Society and } \\
\text { Design }\end{array}$ & Commerce & $\begin{array}{l}\text { All } \\
\text { Respondents }\end{array}$ \\
\hline $\begin{array}{l}\text { Scanning current issues of print } \\
\text { and electronic journals }\end{array}$ & $71 \%$ & $65 \%$ & $75 \%$ & $70 \%$ \\
\hline Previous knowledge & $67 \%$ & $60 \%$ & $63 \%$ & $63 \%$ \\
\hline $\begin{array}{l}\text { Attending professional } \\
\text { conferences, seminars, and } \\
\text { workshops }\end{array}$ & $62 \%$ & $60 \%$ & $63 \%$ & $62 \%$ \\
\hline Discussions with colleagues & $48 \%$ & $50 \%$ & $75 \%$ & $58 \%$ \\
\hline Browsing web pages online & $48 \%$ & $35 \%$ & $65 \%$ & $49 \%$ \\
\hline Browsing Google scholar & $43 \%$ & $40 \%$ & $50 \%$ & $44 \%$ \\
\hline $\begin{array}{l}\text { Browsing Other Online - } \\
\text { Journals/database/archive }\end{array}$ & $33 \%$ & $45 \%$ & $50 \%$ & $43 \%$ \\
\hline Browsing web pages online & $43 \%$ & $40 \%$ & $25 \%$ & $36 \%$ \\
\hline $\begin{array}{l}\text { Scanning recent issues of } \\
\text { abstracting and indexing tools }\end{array}$ & $38 \%$ & $30 \%$ & $13 \%$ & $27 \%$ \\
\hline $\begin{array}{l}\text { Through email alerts (RSS, } \\
\text { Research alerts) }\end{array}$ & $38 \%$ & $30 \%$ & $13 \%$ & $27 \%$ \\
\hline Browsing publishers' catalogues. & $19 \%$ & $25 \%$ & $13 \%$ & $19 \%$ \\
\hline Reading latest books & $19 \%$ & $15 \%$ & $13 \%$ & $16 \%$ \\
\hline Browsing books in library & $14 \%$ & $15 \%$ & $13 \%$ & $14 \%$ \\
\hline Media: newspaper, TV and radio & $5 \%$ & $15 \%$ & $25 \%$ & $15 \%$ \\
\hline Consulting experts in subject field & $10 \%$ & $5 \%$ & $13 \%$ & $9 \%$ \\
\hline $\begin{array}{l}\text { Using social networking website, } \\
\text { such as Face-book, twitter, wikis } \\
\text { etc. }\end{array}$ & $0 \%$ & $5 \%$ & $13 \%$ & $6 \%$ \\
\hline Other (please indicate) & $0 \%$ & $5 \%$ & $0 \%$ & $2 \%$ \\
\hline Browsing blogs & $0 \%$ & $5 \%$ & $0 \%$ & $2 \%$ \\
\hline $\begin{array}{l}\text { Discussion with librarian or } \\
\text { reference staff }\end{array}$ & $0 \%$ & $0 \%$ & $0 \%$ & $0 \%$ \\
\hline
\end{tabular}

The three most-used methods and resources for keeping up-to-date by all respondents are Scanning current issues of print and electronic journals (70\%), Previous knowledge (63\%) and Attending professional conferences, seminars, and workshops (62\%). About half of the respondents reported that they used Discussion with colleagues (58\%) and Browsing web pages online (49\%). Just over two out of five respondents (44\%) reported the use of Google. Respondents seem to use more online resources than hard copy books for getting the latest 
information, with Reading latest books (16\%) and Browsing books in the library (14\%). It is interesting that social networking websites $(6 \%)$ and Blogs $(2 \%)$ are the most unused methods and resources. Nobody has indicated that they have discussion with librarians or reference staff.

Respondents from Commerce seem to have discussions with colleagues (75\%) and browse web pages online (65\%) more than the other two faculties. They also have more respondents in using social networking websites, with $13 \%$ of respondents. 


\subsubsection{Issues}

Respondents were asked to indicate the biggest problems when they are seeking information.

Please select the 3 problems that you encounter most often when you are seeking information.

Table 7, Problems in information-seeking by academics

\begin{tabular}{|c|c|c|c|c|}
\hline Answer & $\begin{array}{l}\text { Agriculture } \\
\text { and Life } \\
\text { Sciences }\end{array}$ & $\begin{array}{l}\text { Environment, } \\
\text { Society and } \\
\text { Design }\end{array}$ & Commerce & $\begin{array}{l}\text { All } \\
\text { Respondents }\end{array}$ \\
\hline Lack of time for searching & $71 \%$ & $57 \%$ & $58 \%$ & $62 \%$ \\
\hline Required material is not available & $44 \%$ & $43 \%$ & $46 \%$ & $44 \%$ \\
\hline $\begin{array}{l}\text { Non availability of electronic resource } \\
\text { (e-journals and databases) }\end{array}$ & $27 \%$ & $38 \%$ & $35 \%$ & $33 \%$ \\
\hline $\begin{array}{l}\text { Information is scattered in too many } \\
\text { resources }\end{array}$ & $44 \%$ & $14 \%$ & $35 \%$ & $31 \%$ \\
\hline $\begin{array}{l}\text { Information explosion or too much } \\
\text { information }\end{array}$ & $33 \%$ & $28 \%$ & $23 \%$ & $28 \%$ \\
\hline Information sources are very expensive & $22 \%$ & $33 \%$ & $23 \%$ & $26 \%$ \\
\hline $\begin{array}{l}\text { Latest information sources are not } \\
\text { available }\end{array}$ & $16 \%$ & $9 \%$ & $0 \%$ & $9 \%$ \\
\hline $\begin{array}{l}\text { Lack of information about available } \\
\text { sources }\end{array}$ & $0 \%$ & $9 \%$ & $12 \%$ & $7 \%$ \\
\hline $\begin{array}{l}\text { Lack of training in electronic } \\
\text { resources/products }\end{array}$ & $5 \%$ & $9 \%$ & $0 \%$ & $5 \%$ \\
\hline $\begin{array}{l}\text { Information sources are located far } \\
\text { away }\end{array}$ & $0 \%$ & $0 \%$ & $12 \%$ & $4 \%$ \\
\hline Lack of technical support & $0 \%$ & $0 \%$ & $12 \%$ & $4 \%$ \\
\hline Lack of computer hardware or software & $5 \%$ & $5 \%$ & $0 \%$ & $3 \%$ \\
\hline Other (please indicate) & $0 \%$ & $9 \%$ & $0 \%$ & $3 \%$ \\
\hline Lack of knowledge in using the library & $5 \%$ & $0 \%$ & $0 \%$ & $2 \%$ \\
\hline Library staff are not available & $0 \%$ & $0 \%$ & $0 \%$ & $0 \%$ \\
\hline $\begin{array}{l}\text { Library staff is incompetent or not well- } \\
\text { trained }\end{array}$ & $0 \%$ & $0 \%$ & $0 \%$ & $0 \%$ \\
\hline Lack of support from library staff & $0 \%$ & $0 \%$ & $0 \%$ & $0 \%$ \\
\hline
\end{tabular}

$62 \%$ of respondents identified the biggest problem in information-seeking is the lack of time for searching. Just over two out of five (44\%) respondents reported that the non-availability of the required materials is a problem. The third reason was that the required electronic resources are not available, with $33 \%$ of respondents. About quarter of the respondents reported information is scattered in too many resources $(31 \%)$, too much information (28\%) and information resources are very expensive (26\%). Almost nobody indicated as a problem 
the lack of knowledge in using the library (2\%), the lack of computer hardware/software (3\%), information sources being located faraway (4\%), the lack of training in electronic resources $(5 \%)$, the lack of information about available resources $(7 \%)$ or latest information sources not being available (9\%). The figures also show that respondents have no problems with library staff and nobody reported that library staff are not available, library staff are incompetent or a lack of support.

Respondents from Agriculture and Life Sciences (71\%) have about 25\% more academics facing a lack of time in information than the other two faculties (57\% \& 58\%). Agriculture and Life Sciences responding academics also have a higher number of problems in experiencing information being scattered in too many resources(44\%), information explosion or too much information(33\%) and latest information sources not being available (16\%) than the other two faculties. Information scattered in too many sources was faced by $14 \%$ of respondents from Environment, Society and Design, and this was the lowest number in all the faculties. 


\subsection{Library Use Questions}

\subsubsection{Usage - LTL website}

Please indicate the uses you have made of the LTL (Library Teaching and Learning) website in the last 6 months (Please check all that apply)

Chart 8, The use of LTL website in last 6 months by all respondents

\section{The Use of LTL Website}

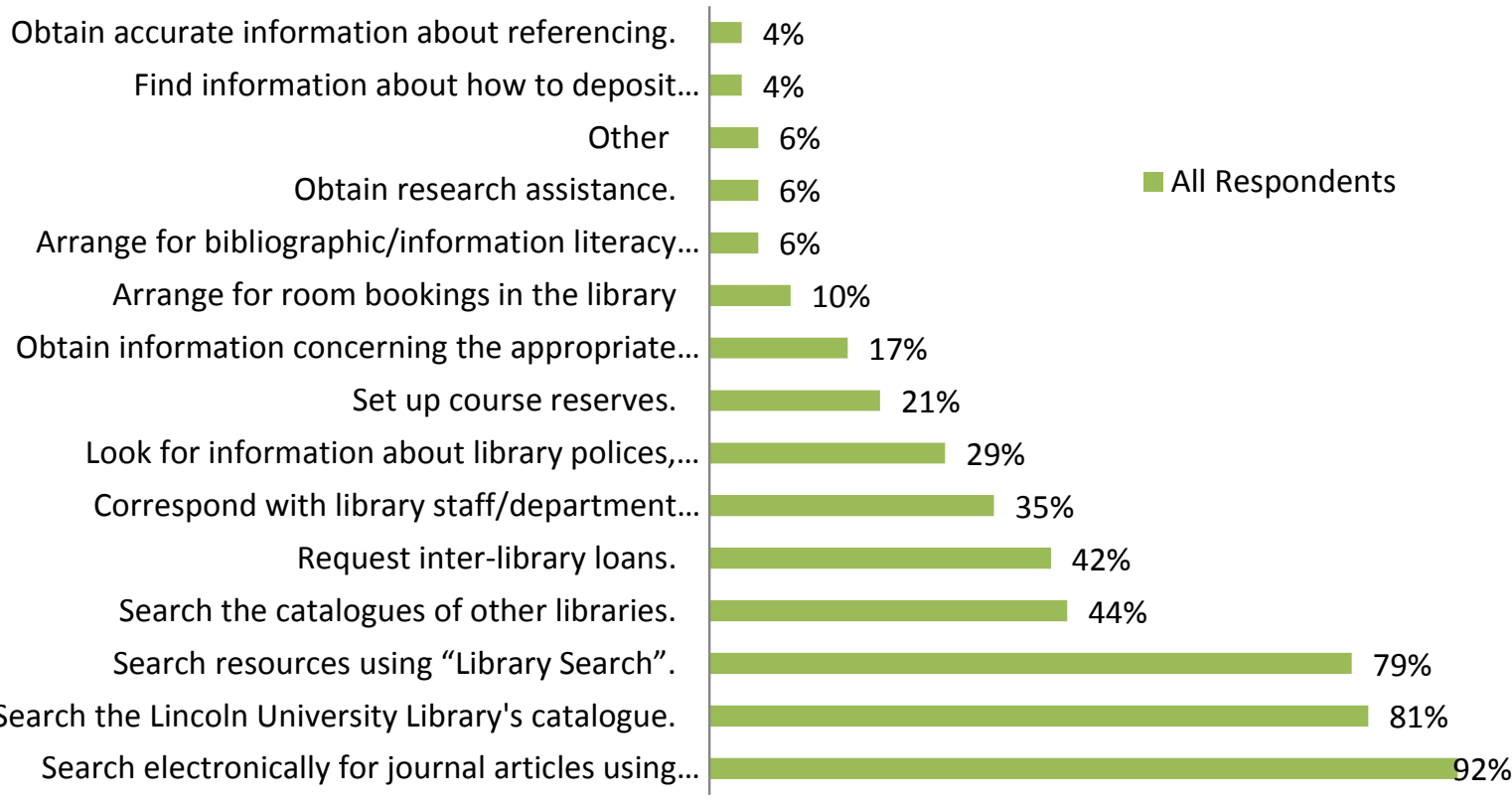

The chart above shows the most-used online Lincoln University Library resources, with 92\% of respondents searching journal articles via online databases, $81 \%$ of respondents searching the Lincoln University Library catalogues and 79\% of respondents using "Library Search" engine. Just over two out of five respondents reported that they use inter-loan services (42\%) and other libraries catalogues (44\%) via LTL website. Almost nobody recorded that they used LTL website to gain referencing information (4\%), gain deposit research information (4\%), obtain research assistance (6\%), arrange bibliographic/information literacy instruction (6\%) or arrange room bookings in the library (10\%). 
Table 8, The use of LTL website in last 6 months by faculties

\begin{tabular}{|llll|}
\hline Answer & $\begin{array}{l}\text { Agriculture } \\
\text { and Life } \\
\text { Sciences }\end{array}$ & $\begin{array}{l}\text { Environment } \\
\text { Society and } \\
\text { Design }\end{array}$ & Commerce \\
\hline $\begin{array}{l}\text { Search electronically for journal articles using } \\
\text { databases. }\end{array}$ & $93 \%$ & $90 \%$ & $93 \%$ \\
\hline Search the Lincoln University Library's catalogue. & $88 \%$ & $76 \%$ & $81 \%$ \\
\hline Search resources using "Library Search". & $82 \%$ & $76 \%$ & $81 \%$ \\
\hline Search the catalogues of other libraries. & $33 \%$ & $62 \%$ & $23 \%$ \\
\hline Request inter-library loans. & $55 \%$ & $38 \%$ & $23 \%$ \\
\hline $\begin{array}{l}\text { Correspond with library staff/department liaison } \\
\text { person }\end{array}$ & $49 \%$ & $28 \%$ & $23 \%$ \\
\hline $\begin{array}{l}\text { Look for information about library policy, hours, and } \\
\text { services. }\end{array}$ & $38 \%$ & $28 \%$ & $12 \%$ \\
\hline Set up course reserves. & $11 \%$ & $24 \%$ & $35 \%$ \\
\hline $\begin{array}{l}\text { Obtain information concerning the appropriate } \\
\text { utilization of copyrighted information. }\end{array}$ & $16 \%$ & $19 \%$ & $12 \%$ \\
\hline Arrange for room bookings in the library & $16 \%$ & $5 \%$ & $12 \%$ \\
\hline $\begin{array}{l}\text { Arrange for bibliographic/information literacy } \\
\text { instruction. }\end{array}$ & $0 \%$ & $14 \%$ & $0 \%$ \\
\hline Obtain research assistance. & $0 \%$ & $5 \%$ & $23 \%$ \\
\hline Other & $0 \%$ & $9 \%$ & $12 \%$ \\
\hline $\begin{array}{l}\text { Find information about how to deposit research } \\
\text { outputs in the Research Archive database. }\end{array}$ & $11 \%$ & $0 \%$ & $0 \%$ \\
\hline Obtain accurate information about referencing. & $5 \%$ & $5 \%$ & $0 \%$ \\
\hline
\end{tabular}

Respondents from Environment, Society and Design search the catalogues of other libraries via LTL (62\%) almost twice as often as the respondents from Agriculture and Life Sciences (33\%) and Commerce (23\%). More respondents from Agriculture and Life Sciences (55\%) make use of the inter-library loan services online than Environment, Society and Design (38\%) and Commerce (23\%). Additionally, respondents from Agriculture and Life Sciences correspond with library staff and gain information about library policy, hours and services more than the other two.

Not many of the faculty respondents search for information using Research Archive database from LTL website very much, with 11\% from Agriculture and Life Sciences and nobody from the other two faculties. 


\subsubsection{Usage - Library services/resources}

I have used the following library services/resources during the past 6 months.

Table 9, The use of Lincoln University Library services and resources in the last 6 months

\begin{tabular}{|c|c|c|c|c|}
\hline Answer & $\begin{array}{l}\text { Agriculture } \\
\text { and Life } \\
\text { Sciences }\end{array}$ & $\begin{array}{l}\text { Environment, } \\
\text { Society and Design }\end{array}$ & Commerce & $\begin{array}{l}\text { All } \\
\text { Respondents }\end{array}$ \\
\hline $\begin{array}{l}\text { Electronic databases } \\
\text { /article indexes }\end{array}$ & $97 \%$ & $83 \%$ & $91 \%$ & $90 \%$ \\
\hline $\begin{array}{l}\text { Electronic journals } \\
\text { (E-Journals) }\end{array}$ & $97 \%$ & $83 \%$ & $79 \%$ & $87 \%$ \\
\hline $\begin{array}{l}\text { Traditional printed } \\
\text { resources (e.g. books, } \\
\text { reference materials, } \\
\text { periodicals) }\end{array}$ & $91 \%$ & $74 \%$ & $79 \%$ & $82 \%$ \\
\hline Electronic books (E-Books) & $64 \%$ & $37 \%$ & $57 \%$ & $53 \%$ \\
\hline Inter-library loan & $54 \%$ & $46 \%$ & $34 \%$ & $45 \%$ \\
\hline Meeting/research space & $48 \%$ & $32 \%$ & $34 \%$ & $38 \%$ \\
\hline $\begin{array}{l}\text { Laptop/technology } \\
\text { equipment checkout }\end{array}$ & $21 \%$ & $9 \%$ & $34 \%$ & $22 \%$ \\
\hline Facilities for class instruction & $16 \%$ & $23 \%$ & $11 \%$ & $17 \%$ \\
\hline $\begin{array}{l}\text { Video/ Audio materials } \\
\text { (e.g. DVD,CD, Micro-fiche) }\end{array}$ & $27 \%$ & $9 \%$ & $11 \%$ & $16 \%$ \\
\hline Computer access & $21 \%$ & $14 \%$ & $11 \%$ & $16 \%$ \\
\hline Research Archive service & $5 \%$ & $9 \%$ & $11 \%$ & $9 \%$ \\
\hline $\begin{array}{l}\text { Special collections/rare } \\
\text { books }\end{array}$ & $0 \%$ & $0 \%$ & $11 \%$ & $4 \%$ \\
\hline Staff library introduction & $5 \%$ & $0 \%$ & $0 \%$ & $2 \%$ \\
\hline Reference service & $0 \%$ & $5 \%$ & $0 \%$ & $2 \%$ \\
\hline $\begin{array}{l}\text { Other (please indicate, } \\
\text { IT help desk ) }\end{array}$ & $5 \%$ & $0 \%$ & $0 \%$ & $2 \%$ \\
\hline $\begin{array}{l}\text { Virtual reference service } \\
\text { (e.g. "Ask us") }\end{array}$ & $0 \%$ & $0 \%$ & $0 \%$ & $0 \%$ \\
\hline
\end{tabular}

The above table shows the most-used services and resources by all Lincoln University respondents are electronic databases/indexes (90\%), electronic journals (87\%), traditional printed resources (82\%), electronic books (53\%) and inter-loan Library services (45\%). Just under two out of five responding academics reported the use of Lincoln University Library as a meeting and research space. About one out of ten respondents check out equipment from the library. Almost nobody indicated the use of rare books (4\%), staff library introduction (2\%) or references services (2\%), and nobody claimed the use of virtual references services (0\%). 
Several interesting similarities and differences emerged between the faculties. Traditional printed resources and electronic books were a very popular use by respondents from Agriculture and Life Sciences, with 91\% in traditional printed resources and 64\% in electronic books. Respondents from Agriculture and Life Sciences also use more inter-library loan services than Environment, Society and Design and Commerce. $23 \%$ of respondents from Environment, Society and Design use the library as place for their class more than respondents from Agriculture and Life Sciences (16\%) and Commerce (11\%).

\subsubsection{Library use in teaching}

When preparing a course Web page, I provide links to electronic databases and other electronic resources available from Lincoln University Library

Chart 9, The use of Lincoln University Library online resources for teaching

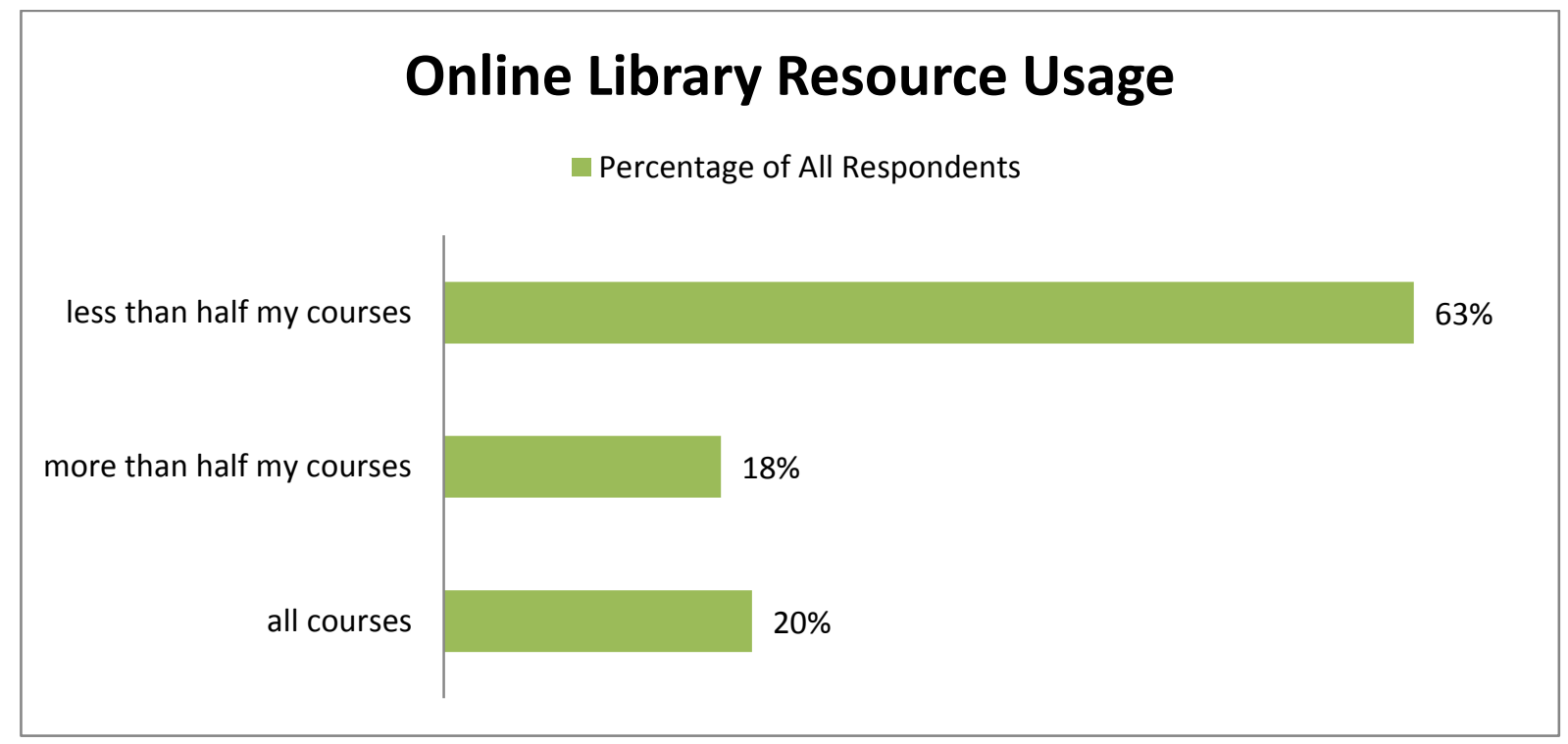

About three out of five (63\%) responding academics provide Lincoln University Library electronic resources links in less their less than half of their course online. Conversely, one out of five respondents (20\%) used electronic databases/resources on all their course web pages. 
For courses that I teach, I utilise traditional (e.g. short-loan collection, books in the library) reserve services at Lincoln University Library.

Chart 10, The use of Lincoln University Library traditional reserve resources for teaching

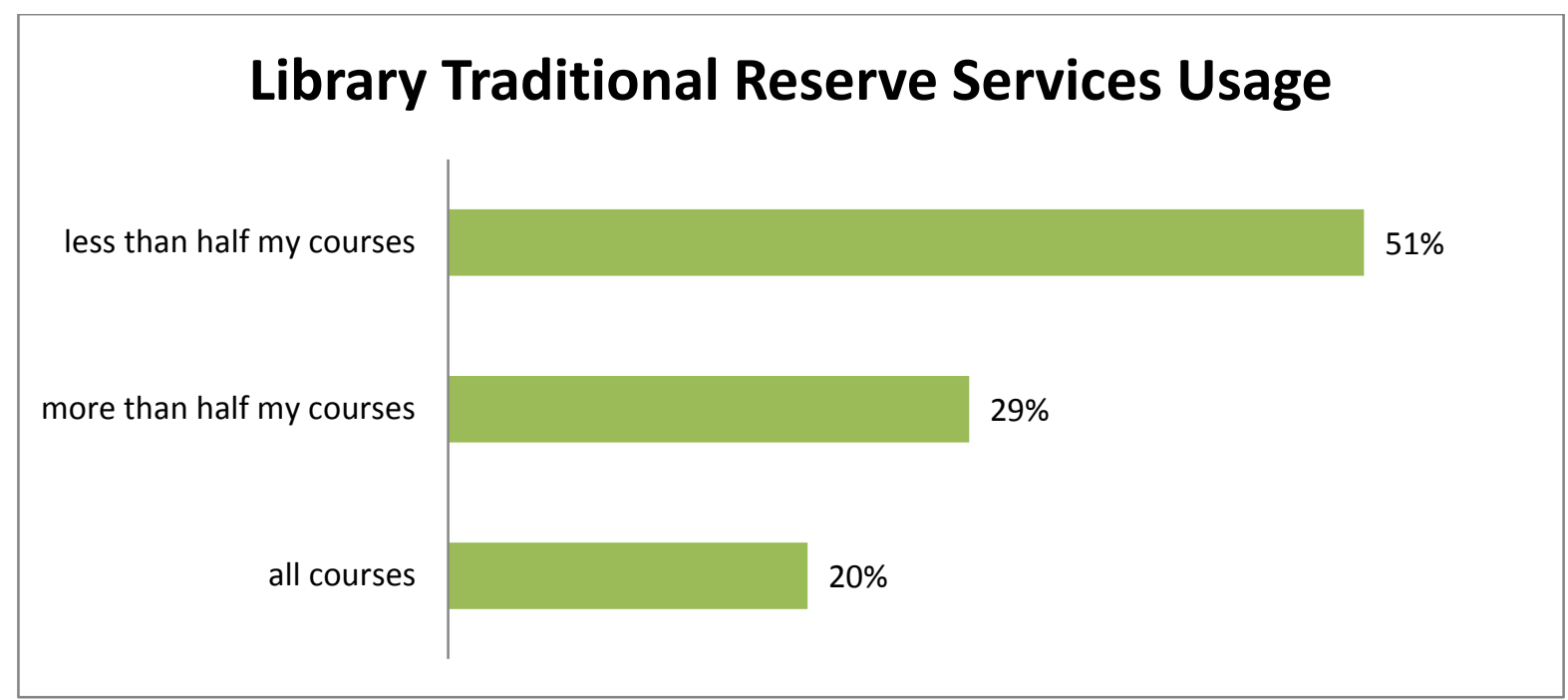

Just over half of the respondents (51\%) indicated that less than half of the courses used traditional reserve services from Lincoln University Library. Slightly more than one quarter (29\%) indicated that more than half of their course used Lincoln University Library resources traditionally. One out of five respondents (20\%) used traditional reserve services.

For courses that I teach, I recommend the use of electronic resources/databases at Lincoln University Library

Chart 11, The recommendation made by academics about use of Lincoln University Library online resources

\section{Electronic Resources Recommendation}

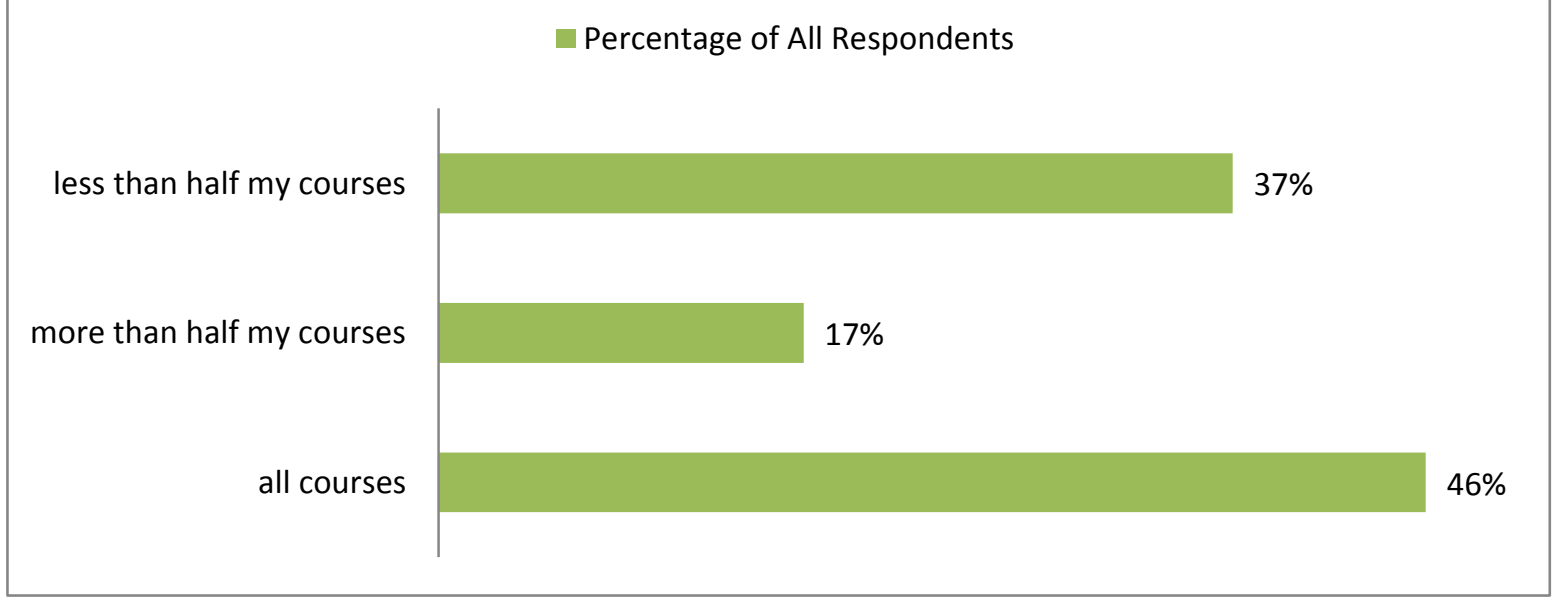

Just under half (46\%) of surveyed academics reported that they recommended the electronic resources/databases from Lincoln University Library in their teaching. Nearly two 
out of five (37\%) respondents said that they recommend the use of electronic resources from Lincoln University library in less than half of their courses. Only a few respondents $(17 \%)$ said more than half their courses.

Lincoln University Library has supported my teaching by........?

Table 10, "Lincoln University Library has supported my teaching by...?"

\begin{tabular}{|c|c|}
\hline Answer & $\begin{array}{l}\text { All } \\
\text { Respondents }\end{array}$ \\
\hline Providing access to materials for inclusion in lectures and reading assignments. & $72 \%$ \\
\hline Purchasing print and electronic materials relevant to my field of study. & $70 \%$ \\
\hline Providing access to subject databases and indexes. & $63 \%$ \\
\hline $\begin{array}{l}\text { Providing information concerning the appropriate use and distribution of } \\
\text { copyrighted materials. }\end{array}$ & $58 \%$ \\
\hline $\begin{array}{l}\text { Providing access to materials that have contributed to the conceptual framework of } \\
\text { courses. }\end{array}$ & $49 \%$ \\
\hline Providing information and assistance student research work. & $44 \%$ \\
\hline Providing information and assistance regarding the use of new resources. & $33 \%$ \\
\hline Other & $5 \%$ \\
\hline
\end{tabular}

Providing access to materials for inclusion in lectures and reading assignments was identified as the most supported reason for academics to use Lincoln University Library in teaching, with $72 \%$ of respondents. The next top reason was that the library had purchased relevant print and electronic materials to their course, with $70 \%$ of respondents. Just over three out of five (63\%) of respondents identified that the library had provided access to subject databases and indexes. About three out of five (58\%) respondents said the library had supported their teaching by providing information about the appropriated use and distribution of the copyrighted materials. However, Lincoln University Library needs to work more on assistance with the use of the latest resources, with only $33 \%$ of respondents. 


\subsection{Satisfaction Level Questions}

\subsubsection{Library staff}

Please indicate the degree to which you agree or disagree with the following statements: I usually find library staff very helpful in answering my questions.

Chart 12, Helpfulness of Lincoln University Library staff

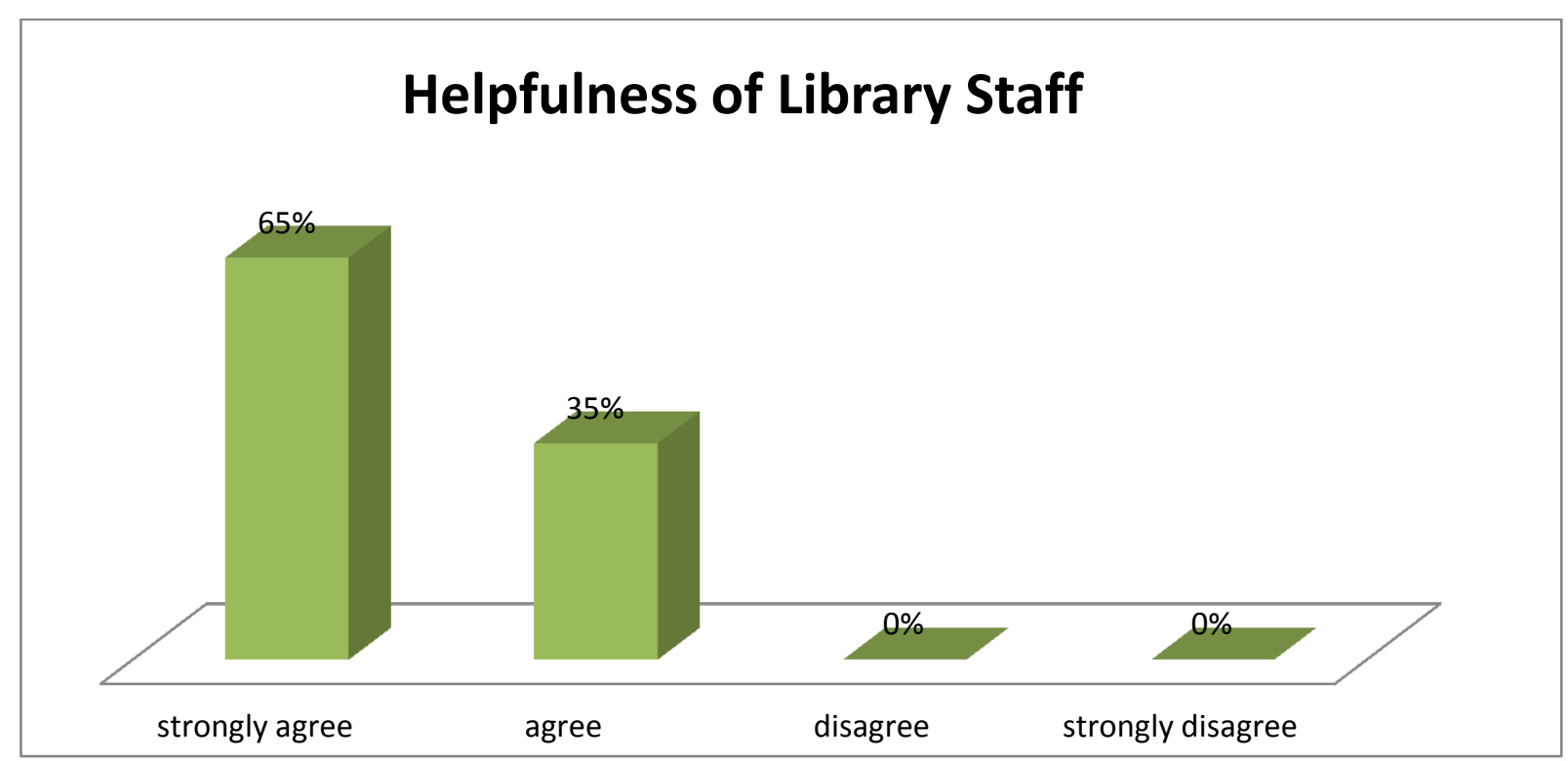

All respondents indicated that the Lincoln University staff are helpful.

\subsubsection{Accessing}

I usually find the books I need at Lincoln University Library.

Chart 13, Availability of books at Lincoln University Library

\section{Availability of Books}

Percentage of All Respondents

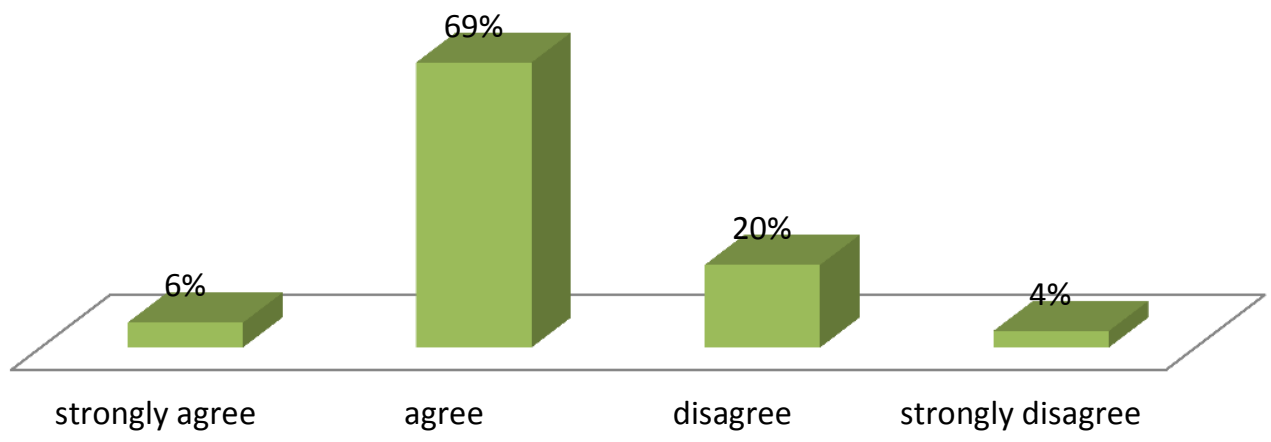


$69 \%$ of respondents agreed that they could find the books they needed at Lincoln University Library, while $20 \%$ disagreed.

I usually find the print periodicals and journals I need at Lincoln University Library.

Chart 14, Availability of print journals at Lincoln University Library

\section{Availability of Print Journals}

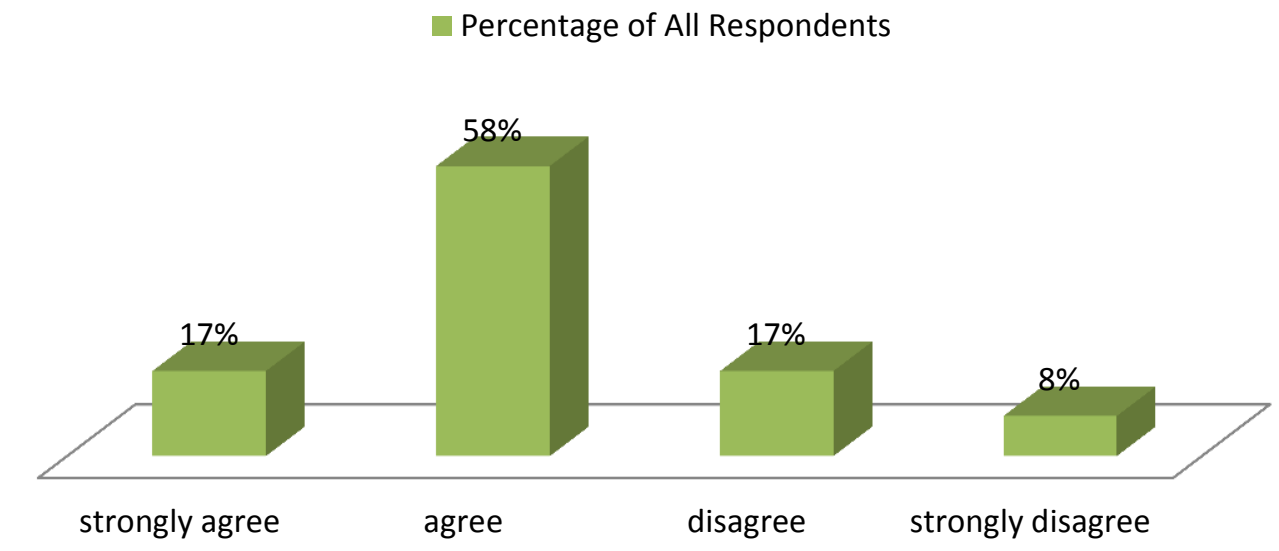

More than half of respondents (58\%) agree and $17 \%$ of respondents strongly agree that they can find print journals at Lincoln University Library, while 17\% of respondents disagreed and $8 \%$ of respondents strongly disagreed.

I can usually access the electronic resources I need at Lincoln University Library.

Chart 15, Accessibility of electronic resources at Lincoln University Library

\section{Accessibility of Electronic Resources}

Percentage of All Respondents

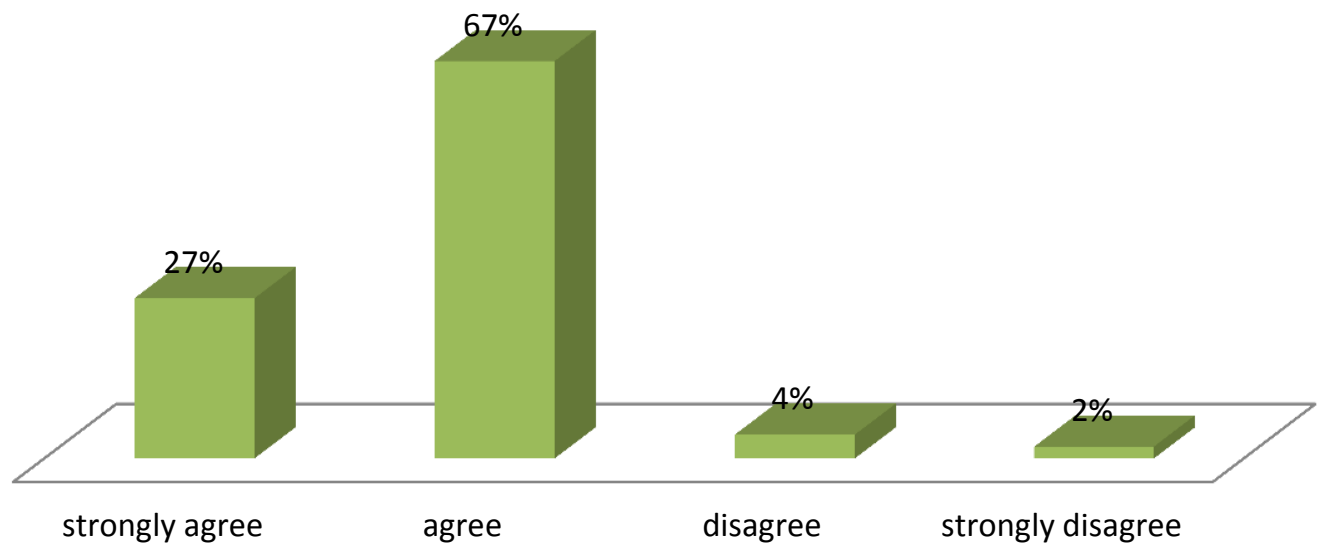


Most responding academics are happy with the accessibility of electronic resources at Lincoln University Library. $27 \%$ of respondents strongly agreed and $67 \%$ agreed that they can access the electronic resources they needed.

\subsubsection{Keeping up-to-date}

I usually use library resources for keep up-to-date in my field.

Chart 16, The use of Lincoln University Library resources for keeping up-to-date

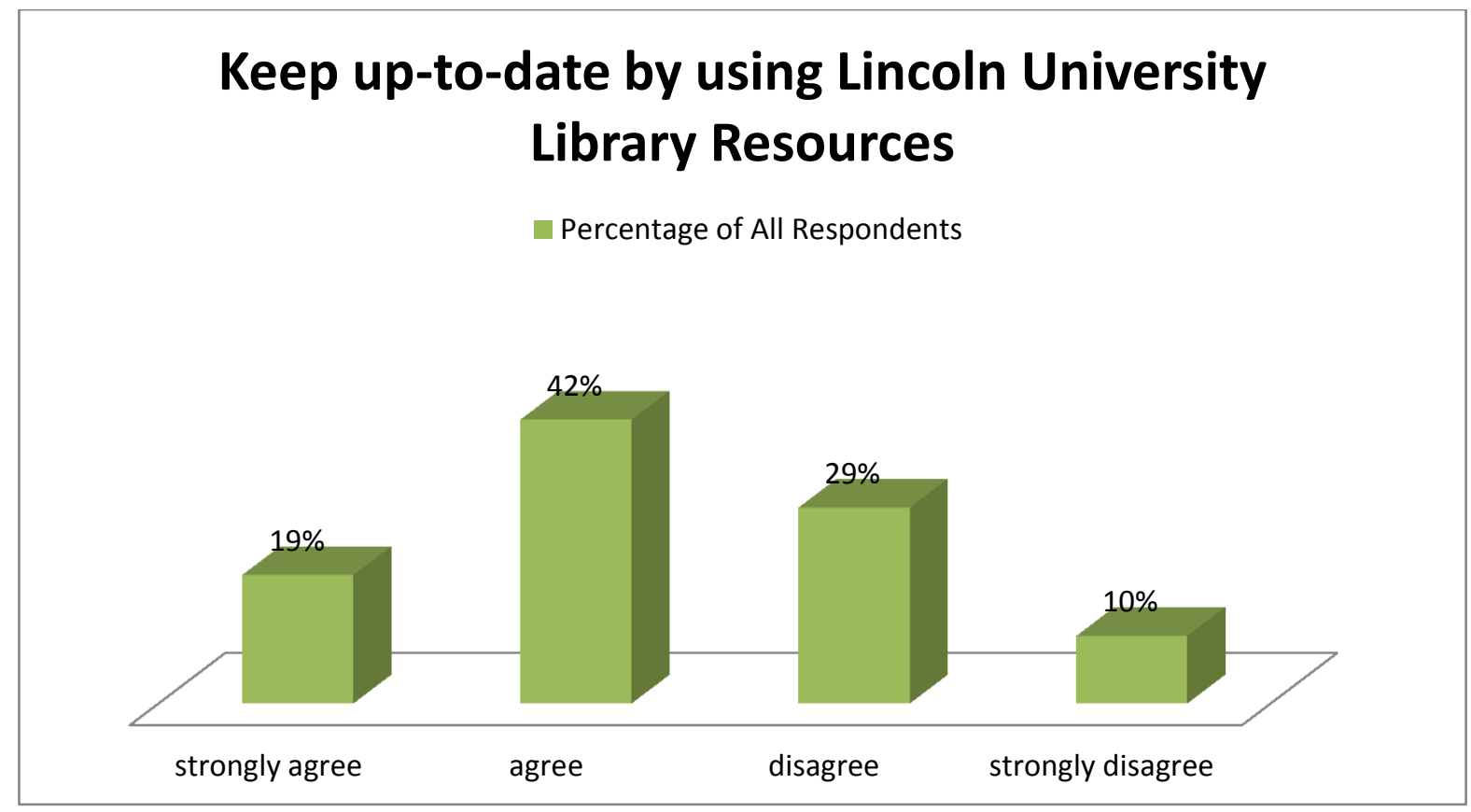

Three out of five responding academics (61\%) use Lincoln University Library resources for getting the latest information in their field. Two out of five (39\%) do not rely on Lincoln University Library resources for obtaining the latest information in their field. 


\subsubsection{Google}

I usually find the materials I need via Google.

Chart 17, The use of Google in finding materials

\section{Findability of Google}

Percentage of All Respondents

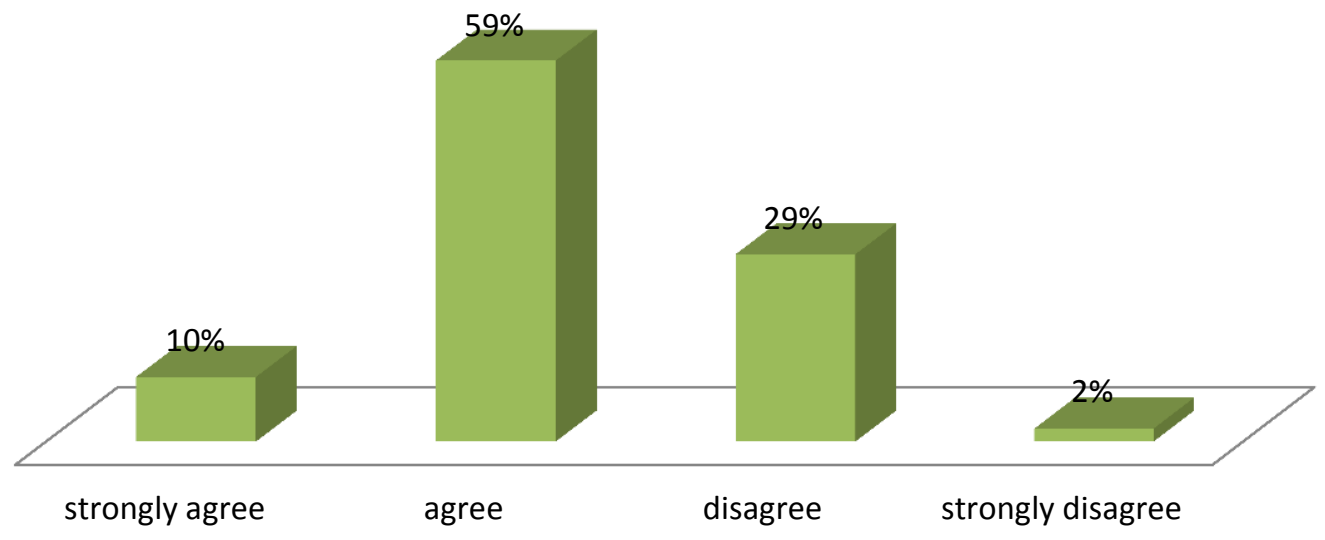

Seven out of ten (69\%) responding academics strongly agreed or agreed that they could find the materials on Google. In contrast, the corresponding figures for respondents disagreeing and strongly disagreeing that Google is a good tool to find the materials they need are $29 \%$ and $2 \%$ respectively. 


\section{Discussion}

\subsection{Information-seeking Behaviours}

Many studies (Kuruppu \& Gruber, 2006; Marchionini, 1995) have shown the digital environment has made electronic resources the core resources for academics in higher education.

The findings of this present study clearly confirmed that electronic resources are important to academics across all faculties, with respondents using $80 \%$ of their time accessing Lincoln University Library resources remotely, compared with $20 \%$ of their time at the library. The study also found that academics prefer printed books more than electronic books, although electronic resources have been popular. Printed books were the second preferred format for academics, with over half of the respondents (55\%).

Overall, the perception amongst all respondents was absolutely clear that electronic is the main format for them, but printed books are also important in information-seeking by academics.

\subsubsection{Devices}

The findings of this present study clearly indicated that the majority of respondents do not use the latest devices for their information-seeking, such as smart phones, tablets, or eReaders. Desktops (96\%) and laptops (75\%) were the main devices used by academics. Only a few respondents reported they have used tablets (21\%), smart phones (13\%), or eReaders (2\%), which confirms Thompson's (1999) argument that academics do not use the latest technologies.

\subsubsection{Methods}

Ally (2001) found that the internet and emails are commonly-used tools in teaching and research, and Nicholas, Williams, Rowlands and Jamali (2010) also stated that internet resources are the first choice for academics. The findings of this present study (see Chart 7) shows $93 \%$ of respondents used internet sources, $80 \%$ of respondents used emails, and $62 \%$ of respondents used oral personal communication, which echoes the findings of Ally (2001) 
and Nicholas et al (2010). The oral personal communication also confirms the finding of Debra Engel et al (2011) that academics often obtain information sources from the people who have a close working relationship with them.

\subsubsection{Search engines}

Nicholas et al (2010) stated that academics from all disciplines prefer the use of gateway search engines, such as Google Scholar and Google. Haglud and Olsson (2008) found that academics were confident with their information-seeking on gateway electronic information. Jamali and Asadi (2010) also found that "academics are also heavy users of Google for research purposes".

The findings of this present study confirm the findings of the above researchers. It shows responding academics use a lot of their time in accessing gateway search engines, with $59 \%$ of their time. Seven out of ten responding academics reported that they are confident with the findability of materials on Google.

\subsubsection{Keeping up-to-date}

The study found that journal articles are the most-used resource for accessing the latest information, with $70 \%$ of academics indicating they use this source the most. The findings also indicate the next most-used resource or method is the use of existing knowledge in keeping up-to-date in the field (63\%). Communication with people in the same field $(62 \%)$ is also important in getting the latest information, such as attending professional conferences, seminars, and workshops and discussion with colleagues. Overall, respondents seem to use more online resources than hard-copy materials to get the latest information.

The study also shows that Lincoln University Library resources were used by three out of five academics (61\%) to keep up-to-date with the latest information.

\subsubsection{Use of social networking sites}

Ji-Hong (2010) found that academics are not interested in these SNS (Social Networking Sites). The findings of this present study shows similar results to Ji-Hong (2010), with fewer academics indicating the use of social networking website $(6 \%)$ and blogs $(2 \%)$ to obtain information. 


\subsubsection{Issues}

Kuruppu and Gruber (2006) indicated that academic users lack knowledge and skills in finding information but the present study shows that academics are confident with their search skills and use of the library, with only a couple of respondents reporting a lack of skills and knowledge when they are seeking information.

The present study found that the biggest problem in information-seeking by academics is the lack of time. Three out of five responding academics felt that they do not have enough time to search for information. Academics also have issues with accessing the materials they needed, with $44 \%$ of respondents reporting that the non-availability of the required materials was a problem, and $33 \%$ of respondents reported that the required electronic resources are not available. This confirms the findings of information research network from the UK (Overcoming Barriers: access to research information, 2009), in which academics face difficulties in accessing e-content.

The finding of this study shows that most academics do not have technical issues, with only a couple of people indicating they have problems with soft-/hardware. The findings also show academics have no issues with technical support. This finding contradicts the finding from both information research networks from the UK (Overcoming Barriers: access to research information, 2009) and Nicholas, Huntington, Jamali, Rowlands and Fieldhouse (2009).

\subsubsection{Comparisons between faculties}

These findings from the present study show that respondents from all faculties have very similar information-seeking behaviours but there are some differences as well.

In terms of resource preferences, the finding of this study has shown that electronic resources, especially electronic journal articles, are the most preferred and most important information sources in all subject disciplines, which confirms the findings from Friedlander (2003), Tenopir and King (2001, 2002), Tenopir, King, \& Bush (2004) and Tenopir, King, Montgomery and Aerni (2003). However, more respondents from the faculty of Agricultural and Life Science use electronic journals articles than respondents from Commerce, which is in line with Tenopir et al. 's (2003) finding of scientists using more electronic journals than humanists or those in the social sciences. Respondents from Agriculture and Life Sciences 
also spent more time using the library remotely than the other two faculties. Over half of respondents across all faculties have indicated printed books are important for them. More respondents from Commerce prefer using printed journals (34\%) and manuscripts documents (34\%) than the other two faculties.

When it comes to the use of other library catalogues from LTL website, respondents from Agriculture and Life Sciences and Environment, Society and Design reported a very low usage of other library catalogues. Nobody from Commerce indicated the use of other libraries' catalogues.

Respondents from Commerce reported using methods of discussions with their colleagues, browsing web pages online and using social networking websites to gain information more than the other two faculties.

In terms of academics experiencing issues in information-seeking, the present study shows that more respondents from Agriculture and Life Sciences face a time shortage issue and information overload in information-seeking than the other two faculties.

\subsection{Library Use}

\subsubsection{At-library}

Hiller (2002) indicated that academics spend more time accessing the library remotely than visiting the library physically, which is true in the present study as well, with all respondents using about $20 \%$ of their time in the library. The findings of the present study show that checking out library materials, the availability of specific materials in the library and viewing new items in the library were the main reasons for attracting academics to visit the library in person. The study also found that a very few academics use the library as a place for their teaching and research.

Hemminger, Lu, Vaughan and Adams (2007) stated “...the most common reasons for researchers visiting the library were for other services, such as photocopying, teaching, catching up with friends and dropping off print materials". The findings of the present study support the previous data that academics to go to the physical library for teaching and dropping off print materials. However, the present study has failed to support Hemminger, Lu, Vaughan and Adams' (2007) finding that academics use library equipment. 


\subsubsection{Services and resources}

The present study indicates that, overall, academics prefer online materials over printed materials, as academics spend four times longer in accessing online resources than in going to the library.

The library website is the core online resource used by academics because it is an access point to other databases and electronic journals. The findings of this study show the mostused services and resources from Lincoln University library were electronic databases/indexes (90\%) and electronic journals (87\%). This finding supports Nicholas et al's (2009) finding that "...most users used the library web as a bridge to access scholarly databases".

In terms of accessing libraries' catalogues, the present study shows the majority of academics hardly ever access other library catalogues via LTL website. However, they use "library search" and Lincoln University Library catalogue, with $81 \%$ of respondents.

Very few academics indicated that they have used LTL website to gain information about other stuff, such as: library policy and hours, teaching and research instructions, referencing and room bookings. It is interesting that academics are not aware of new library services. The new online referencing tool ("Ask us") was hardly used by academics.

The findings of this study disagree with Dickenson's (2006) conclusion that inter-loan services were highly used by academics ( $75 \%$ of responding academics indicated they have used it). However, in this present study, inter-loan services were not highly used and only just over two out of five respondents (42\%) reported the use of inter-loan services in the past six months.

Overall the findings of this study show academics have a very strong connection with Lincoln University Library's resources, both in digital and printed resources. It refutes Sennyey et al.'s (2009) view that the academic library will be removed in the future.

\subsubsection{Use of the library in teaching}

The present study shows the collections in the library have been a great support for academics in teaching. Academics strongly recommend their students to use the library but 
more academics recommend the use of Lincoln University Library resources than they actually use Lincoln University Library resources in teaching, with only one out of five respondents reporting that they have used Lincoln University electronic and traditional restricted loan and other services in all courses.

When it comes to the working relationship between library staff and academics, the findings show that responding academics have not been in much regular contact with library staff, which shows the existing library liaison services are not well utilised.

\subsubsection{Satisfaction}

The findings of the present study show that the majority of academics are satisfied with Lincoln University Library staff and collections.

- All respondents indicated that the Lincoln University staff are helpful.

- $69 \%$ of respondents agreed that they could find books they needed at Lincoln University Library.

- More than half of respondents (58\%) agreed and $17 \%$ of respondents strongly agreed that they could find print journals at Lincoln University Library.

- $27 \%$ of respondents strongly agreed and $67 \%$ agreed that they could access the electronic resources they needed from Lincoln University Library.

- Three out of five responding academics (61\%) used Lincoln University Library resources to get the latest information in their field.

- Nobody reported issues in information-seeking because library staff are incompetent or because of a lack of support.

The findings above are consistent with the earlier studies of Primary Research Group (2009) and Adeniran (2011). 


\section{Conclusion}

Overall, this study has provided the latest knowledge about academic users' informationseeking behaviours in a New Zealand university. It has enhanced a real-life understanding of academics' information-seeking behaviour at Lincoln University and the use of their university library in teaching, as well as their satisfaction with the library. The present study used an online survey to collect data with an effective response rate. The present study concluded the following points: electronic journals and printed books are important components in academics' information-seeking; most academics have not adapted to the latest information technologies; academics experience a lack of time in information-seeking; academics use more online resources to gain the latest information, such as electronic journal articles; academics do not make use of librarians in information-seeking and teaching; academics are not aware of the latest changes in the library, but they are satisfied with Lincoln University Library's services and resources.

Based on the present findings, some suggestions and recommendations for improving the situation are detailed below:

- The library should continue to have both electronic resources and printed resources. The main focus should be on having journal articles in both electronic and printed forms and printed books.

- Librarians should provide training and guidance for academics on using the latest information-seeking technologies and raising awareness of the full range of library services and resources.

- Librarians and the library system must do better to provide efficiency in accessing resources to provide time lost in the information-seeking process. New informationseeking tools and skills should be introduced from time to time by librarians.

- Library systems need to look and function more like Google search engine as academics are confident in using it.

- The need to improve the communication and collaboration between librarians and academics. Librarians need to work closely with academics to improve library services in teaching. Subject librarians are recommended to deal with issues and 
promote library services and resources more specifically according to the subject needs.

- Librarians need to encourage academic staff to use more Lincoln University Library services and collections in teaching - for example, promote new library resources and services by organising training sessions.

- The library needs to advertise the new resources better to academics - for example, organising the latest subjects' resources and services handouts by sending emails or newsletter to academics.

Future research addressing Lincoln University academic library users is still needed and the present study is suggesting that there is a need for a wide-ranging user behaviours study to address how Lincoln University Library users find information in different contexts and situations. Future research work should take into consideration the study of: undergraduate or postgraduate students, international students, and visitors' information-seeking behaviours and their use of Lincoln University Library. Additionally, due to the limited funding and time of this study, a future study may focus on the broader picture by exploring the common patterns and stages of academic users' information-seeking behaviour by interview or observation. These suggestions could provide more valuable data that would improve the Lincoln University Library resources and services in the future.

Words: 12,256 


\section{References}

Adeniran, P. (2011). User satisfaction with academic libraries services: academic staff and students perspectives. International Journal of Library and Information Science 3(10), 209-216.

Analyst Claims UK Libraries in Decline; CILIP Begs to Differ. (2004). Retrieved July 31, 2012,from

https://www.ala.org/ala/alonline/currentnews/newsarchive/alnews2004/april2004a $\underline{\text { b/cilip.cfm }}$

Badke, W. (2009). Google Scholar and the researcher. Online, 33(3).

Belefant-Miller, H., \& King, D. W. (2000). How, What, and Why Science Faculty Read. Science \& Technology Libraries, 19(2), 91-112. doi:10.1300/J122v19n02_08

Broadus, R. N. (1977). Evaluation of academic library collections: A survey of recent literature. Library Acquisitions: Practice and Theory, 1(3), 149-155.

Brophy, J., \& Bawden, D. (2005). Is Google enough? comparison of an internet search engine with academic library resources. Aslib Proceedings, 57(6), 498-512.

Brown, C. (2010). Communication in the sciences. Annual Review of Information Science and Technology, 44(1), 285-316. doi:10.1002/aris.2010.1440440114

Bryman, A. (2012). Social research methods (4th ed.). Oxford ; New York: Oxford University Press.

Case, D. O. (2002). Looking for Information: A Survey of Research on Information Seeking, Needs, and Behavior. San Diego CA: Academic Press.

Case, D. O. (2007). Looking for information : a survey of research on information seeking, needs, and behavior (2nd ed.). Amsterdam ; Boston: Elsevier/Academic Press. Retrieved from http://www.loc.gov/catdir/enhancements/fy0702/2006050838d.html

Choy, F. C. (2011). From library stacks to library-in-a-pocket: Will users be around? Library Management, 32(1), 62-72. doi:10.1108/01435121111102584

Courtright, C. (2007). Context in information behavior research. Annual Review of Information Science and Technology, 41(1), 273-306.

doi:10.1002/aris.2007.1440410113 
Davis, R. A., \& Bailey, C. A. (1964). Bibliography of use studies: Office of Science Information Service National Science Foundation. Retrieved from http://books.google.co.nz/books?id=WtpjAAAAMAAJ

Dervin, B., \& Nilan, M. (1986). Information needs and uses. Annual Review of Information Science and Technology, 21(3-33).

Dickenson, D. (2006). How Academic Libraries Help Faculty Teach and Students Learn The 2005 Colorado Academic Library Impact Study. Retrieved August 7, 2012,from http://www.Irs.org/documents/academic/ALIS final.pdf

Don, D. (2006). How students and faculty use academic libraries differently. Retrieved July 31, 2012,from http://www.Irs.org/documents/fastfacts/242 ALIS 2 KL.pdf

Earle, P., \& Vickery, B. (1969). Social Science Literature use in the UK as indicated by citations. Journal of Documentation, 25(2), 123-141. doi:10.1108/eb026468

Ellis, D. (1987). The derivation of a behavioural model for information retrieval system design (Unpublished doctoral dissertation). University of Sheffield, Sheffield.

Ellis, D. (1989). A behavioral approach to information retrieval system design. Journal of Documentation, 45(2), 171-212. doi:10.1108/eb026843

Ellis, D., Cox, D., \& Hall, K. (1993). A comparison of the information seeking patterns of researchers in the physical and social sciences. Journal of Documentation, 49(4), 356369. doi:10.1108/eb026919

Ellis, D., \& Haugan, M. (1997). Modelling the information seeking patterns of engineers and research scientists in an industrial environment. Journal of Documentation, 53(384403).

Engel, D., Robbins, S., \& Kulp, C. (2011). The Information-Seeking Habits of Engineering Faculty. College \& research libraries, 72(6), 548-565.

Evans, G. E. (2002). Management issues of co-operative ventures and consortia in the USA, Part 1. Library Management, 23(4/5), 213-226.

Friedlander, A. a. B., R.S. , . (2003). The Implications of Information Technology for Scientific Journal Publishing: A Literature Review. Retrieved from http://www.nsf.gov/statistics/nsf03323/pdf/nsf03323.pdf

Garvey, W. D. (1979). Communication, the essence of science : facilitating information exchange among librarians, scientists, engineers, and students. Oxford ; New York: Pergamon Press. 
Griffiths, J. R., \& Brophy, P. (2005). Student searching behavior and the web: Use of academic resources and Google. . Library Trends, 53(4), 539-554.

Group, P. R. (2009). The Survey of Higher Education Faculty: Use of Academic Library Interlibrary Loan Services. Retrieved August 15, 2012,from

http://www.researchandmarkets.com/reports/1145950/the survey of higher educ ation faculty use of

Haglund, L., \& Olsson, P. (2008). The Impact on University Libraries of Changes in Information Behavior Among Academic Researchers: A Multiple Case Study. The Journal of Academic Librarianship, 34(1), 52-59.

Haines, L., Light, J., O'Malley, D., \& Delwiche, F. (2010). Information-seeking behaviour of basic science researchers: implications for library services. Journal of the Medical Library Association, 98(1), 73-81. doi:10.3163/1536-5050.98.1.019

Hartman, K. A., \& Laura, B. M. . (2008). Google scholar and academic libraries: An update. New Library World, 109(5/6), 211-222. doi:10.1108/03074800810873560

Hartman, K. A., \& Laura, B. M., . doi: . (2008). Google scholar and academic libraries: An update. New Library World. New Library World, 109(5), 211-222. doi:10.1108/03074800810873560

Hemminger, B. M., Lu, D., Vaughan, K. T. L., \& Adams, S. J. (2007). Information seeking behavior of academic scientists. Journal of the American Society for Information Science and Technology, 58(14), 2205-2225. doi:10.1002/asi.20686

Hiller, S. (2002). How Different Are They? A Comparison By Academic Area Of Library Use, Priorities, and Information Needs at the University of Washington. Retrieved July 31, 2012,from http://www.istl.org/02-winter/article1.html

Horava, T. (2010). Challenges and possibilities for collection management in a digital age. Library Resources \& Technical Services, 54(3), 142-152.

Jamali, H. R., \& Asadi, S. (2010). Google and the scholar: The role of Google in scientists information-seeking behaviour. Online Information Review, 34(2), 282-294. doi:10.1108/14684521011036990

Jamali, H. R., \& Nicholas, D. (2008). Information-seeking behaviour of physicists and astronomers. Aslib Proceedings, 60(5), 444 - 462.

Ji-Hong, P. (2010). Differences among university students and faculties in social networking site perception and use. The Electronic Library, 28(3), 417-431.

doi:10.1108/02640471011051990 
Kawatra, P. S. (1992). Library User Studies: A Manual for Librarians and Information Scientists: Jaico Publishing House. Retrieved from http://books.google.co.nz/books?id=i6RPAAAACAAJ

King, D. W., McDonald, D. D., \& Roderer, N. K. (1981). Scientific journals in the United States: their production, use, and economics: Hutchinson Ross Pub. Co. Retrieved from http://books.google.co.nz/books?id=ttETqDZDQXAC

Kinnucan, M. T. (1994). Modeling user's preferences for document delivery. OCLC Systems \& Services, 10(2), 93-98. doi:10.1108/10650759410798369

Korobili, S., Malliari, A., \& Zapounidou, S. (2011). Factors that Influence Information-Seeking Behavior: The Case of Greek Graduate Students. The Journal of Academic Librarianship, 37(2), 155-165.

Kotler, P. (2006). Marketing management (12th ed.). NY: Prentice Hall.

Krikelas, J. (1983). Information-seeking behaviour: a pattern and concept. Foundations of Library Practice, 19(2), 5-20.

Kuhlthau, C. C. (1991). Inside the search process: Information seeking from the user's perspective. Journal of the American Society for Information Science, 42(361-371).

Kuhlthau, C. C. (2004). Seeking meaning: a process approach to library and information services: Libraries Unlimited.

Kuruppu, P. U., \& Gruber, A. M. (2006). Understanding the information needs of academic scholars in agricultural and biological sciences. The Journal of Academic Librarianship, 32(6), 609-632.

Lally, E. (2001). A researcher's perspective on electronic scholarly communication. Online Information Review, 25(2), 80-87. doi:10.1108/14684520110390015

Lincoln University. (2012). History of Lincoln Retrieved May,12, 2012,from http://www.lincoln.ac.nz/About-Lincoln-University/lincoln-alumni/About/

Mackenzie, A. (2012). Libraries: championing digital information on campus. Retrieved 1 August 12012,from http://www.guardian.co.uk/higher-educationnetwork/blog/2012/jan/18/information-literacy

Marchionini, G. (1995). Information Seeking in Electronic Environments: Cambridge: Cambridge University Press.

Martell, C. (2008). The Absent User: Physical Use of Academic Library Collections and Services Continues to Decline 1995-2006. The Journal of Academic Librarianship, 34(5), 400-407. 
Martensen, A., \& Gronholdt, L. (2003). Improving library users" perceived quality, satisfaction and loyalty: An integrated measurement and management system. J. Acad. Lib, 29(3), 140-147.

Martinez-Uribe, L., \& Macdonald, S. (2009). A new role for academic librarians: data curation. Retrieved 15 May, 2012,from http://www.era.lib.ed.ac.uk/handle/1842/3207

Matusiak, K. K. (2006). Information Seeking Behavior in Digital Image Collections: A Cognitive Approach. The Journal of Academic Librarianship, 32(5), 479-488.

Mohsenzadeh, F., \& Isfandyari-Moghaddam, A. . (2009). Application of information technologies in academic libraries. The Electronic Library, 27(6), 986-998. doi:10.1108/02640470911004075

Need for academic libraries grows. (2011, 2012/7/31). 42(9-10), 21. Retrieved from http://go.galegroup.com/ps/i.do?id=GALE\%7CA270283922\&v=2.1\&u=lincoln1\&it=r\& $\mathrm{p}=I T O F \& s w=w$

Nicholas, D., Huntington, P., Jamali, H. R., Rowlands, I., \& Fieldhouse, M. (2009). Student digital information-seeking behaviour in context. Journal of Information Science, 65(1), 103-132. doi:10.1108/00220410910926149

Nicholas, D., Williams, P., Rowlands, I., \& Jamali, H. R. (2010). Researchers' e-journal use and information seeking behaviour Journal of Information Science, 36(4), 494-516. doi:10.1177/0165551510371883

Niu, X., Hemminger, B. M., Lown, C., Adams, S., Brown, C., Level, A., . . Cataldo, T. (2010). National study of information seeking behavior of academic researchers in the United States. Journal of the American Society for Information Science and Technology, 61(5), 869-890. doi:10.1002/asi.21307

Ocak, M. A. (2011). Why are faculty members not teaching blended courses? Insights from faculty members. Computers \&amp; Education, 56(3), 689-699.

Overcoming Barriers: access to research information. (2009). Retrieved 9 May, 2012,from http://www.rin.ac.uk/our-work/using-and-accessing-informationresources/overcoming-barriers-access-research-information

Palmer, J. P., \& Sandler, M. (2003). What do faculty want? Library Journal, 128(1), 26-29.

Porter, S. R., \& Whitcomb, M. E. (2003). The impact of contact type on web survey response rates. Public Opinion Quarterly, 67, 579-588.

Primary Research Group. (2009). The Survey of Higher Education Faculty: Level of Faculty Satisfaction with the Academic Library. Retrieved August 12, 2012,from 
http://www.researchandmarkets.com/reports/1091644/the survey of higher educ ation faculty level of

Research Information Network, \& The Consortium of Research Libraries. (2007). Researchers' Use of Academic Libraries and their Services. Retrieved from http://www.rin.ac.uk/our-work/using-and-accessing-informationresources/researchers-use-academic-libraries-and-their-serv

Rice-Livey, M., \& Racine, J. D. (1997). The role of academic librarians in the era of information technology. Journal Of Academic Librarianship, 23(1), 31.

Sennyey, P., Ross, L., \& Mills, C. (2009). Exploring the future of academic libraries: A definitional approach. The Journal of Academic Librarianship, 35(3), 252-259.

Song, Y. (2009). Designing library services based on user needs: new opportunities to reposition the library

World Library and Information Congress: 75th IFLA General Conference and Council 23-27 Retrieved from http://conference.ifla.org/past/ifla75/202-song-en.pdf

Stebelman, S. (1999). Improving library relations with the faculty and university administrators: The role of the faculty outreach librarian. College \& research libraries, 60(2), 121-130.

Stoller, M. (2005). Building library collections: Its still about the user. Collection Building, 24(1), 4-8.

Sun, H., Chen, K., Tseng, C., \& Tsai, W. (2011). Role changing for librarians in the new information technology era. New Library World, 112(7), 321-333. doi:10.1108/03074801111150459

Swigon, M. (2011). Information barriers in libraries: types, typologies and Polish empirical studies. Library Management, 32(6/7), 475-484. doi:10.1108/01435121111158619

Tagliacozzo, R., \& Kochen, M. (1970). Information-seeking behavior of catalog users. Information Storage and Retrieval, 6(5), 363-381.

Tenopir, C., \& King, D. W. (2001). What Do We Know About Scientists' Use of Information in General: The Role of the Literature and Other Information Sources. Paper presented at the meeting of the Metadiversity II: Assessing the Information Requirements of the Biodiversity Community, U.S. Geological Survey and the National Federation of Abstracting and Information Services, Charleston, South Carolina. Retrieved from http://web.utk.edu/ tenopir/speeches/2000 2004.html

Tenopir, C., \& King, D. W. (2002). Reading behaviour and electronic journals. Learned Publishing, 15(4), 259-265. doi:10.1087/095315102760319215 
Tenopir, C., King, D. W., \& Bush, A. (2004). Medical faculty's use of print and electronic journals: changes over time and in comparison with scientists. Medical Library Association, 92(2), 233-241.

Tenopir, C., King, D. W., Montgomery, C. H., \& Aerni, S. E. (2003). Patterns of Journal Use by Faculty at Three Diverse Universities. D-Lib Magazine, 9(10).

Tenopir, C., King, D. W., Spencer, J., \& Wu, L. (2009). Variations in article seeking and reading patterns of academics: What makes a difference? Library \&amp; Information Science Research, 31(3), 139-148.

Thompson, D. (1999). From marginal to mainstream: Critical issues in the adoption of information technologies for tertiary teaching and learning. In A. Tail \& R. Mills (Eds.), The Convergence of Distance and Conventional Education: Patterns of Flexibility of the Individual Learner (150-160). London: Routledge.

Tibbo, H. R. (2004). Information Seeking Behaviours [PowerPoint Presentation]. Retrieved 24 March, 2010,from http://www.delos.info/files/pdf/events/2004 Sett 6 10/TibboInformation-Seeking-Behaviors.pdf

Wallis, L. (2006). Information-seeking behavior of faculty in one school of public health. Medical Library Association, 94(4), 442-446.

Watson, E. M. (2010). Taking the mountain to Mohammed : the effect of librarian visits to faculty members on their use of the library. New Review of Academic Librarianship, 16(2), 145-159. doi:http://dx.doi.org/10.1080/13614533.2010.500922

Weber, M. A., \& Flatley, R. (2006). What do faculty want? a focus group study of faculty at a mid-sized public university. Library Philosophy and Practice, 9(1).

Westbrook, L., \& Tucker, S. A. (2002). Understanding faculty information needs. Reference \& User Services Quarterly, 42(2), 114-148.

Wildemuth, B. M. (2003). Why Conduct User Studies? The Role of Empirical Evidence in Improving the Practice of Librarianship. Retrieved 16 July 2012,from http://www.inforum.cz/archiv/inforum2003/prispevky/Wildemuth Barbara.pdf

Wilson, P. (1983). Second-hand knowledge: An inquiry into cognitive authority. Westport, CT: Greenwood Press.

Wilson, T. D. (1999). Models in information behaviour research. Journal of Documentation, 55(3), 249-270.

Wilson, T. D. (2000). Human information behavior. Informing Science, 3(2), 49-55. 


\section{Appendix A \\ Information Sheet and Reminder Email}

\section{A.1 Information sheet}

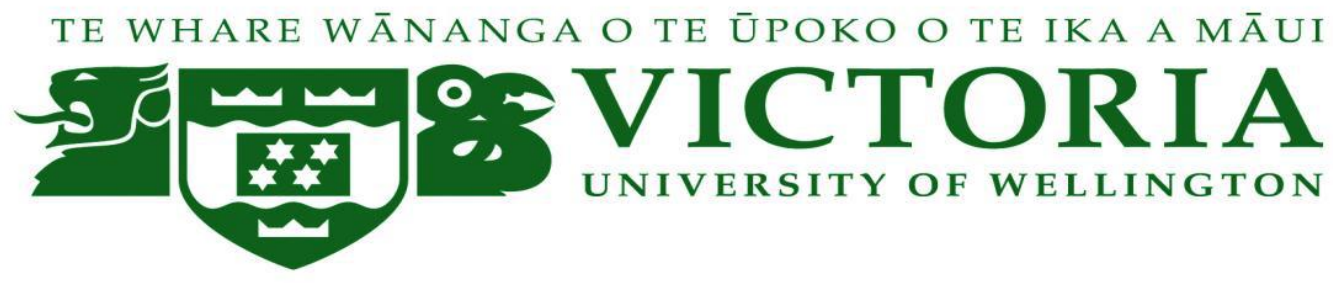

\section{P O Box 84}

Lincoln University

Lincoln 7647

Christchurch

New Zealand

Dear Sir/Madam,

My name is Amanda HE. I am conducting a Research Project as part of my Master of Information Studies in Victoria University of Wellington.

The research project is titled "Library Use and Information Seeking Behaviour of Academics at Lincoln University". The research consists of an online survey asking about what methods and tools are used by academics for information-seeking and whether academics make optimum use of Lincoln University Library. The results of this research will help the Lincoln University Library, Teaching and Learning and other similar institutions to improve their services. This research has been approved by the University Librarian, Professor Penny Carnaby, and by the Human Ethics Committee in the School of Information Management at Victoria University.

I am inviting all academic staff to participate in the research. If you agree to participate, you can click the link button on this page to start the online survey. The survey will take less than 20 minutes to complete and can be submitted online. At the end of the survey, you will have the option to enter a draw for a $\$ 40$ Gift card from PaperPlus store by providing your name, and email address. The winning entries will be drawn randomly and the prize winner will be 
contacted by email. Your contact details are requested only for the prize draw and will be stored in a separate database. Your submission of the survey implies your consent to take part in this project.

Your response will be kept strictly confidential. This means:

- Your participation in this study is completely voluntary and your responses will remain anonymous. Your answers cannot be matched to your identity and will be released only as summaries grouped with other people's responses.

- If you choose to enter your contact information to be in the prize draw and/or receive a summary of the findings, this information will not be linked to your survey responses, will be kept in a password protected file on a secure server, and will be deleted once the findings have been communicated.

- You may withdraw prior to submitting your survey, without consequences of any kind. To leave the study, simply close the web browser window. Once you have submitted your survey, it is no longer possible to withdraw your data because your responses are entered into a non-identifiable data file.

The aggregate responses will form part of my written report and may also be used in a conference presentation. The information collected will be kept in a locked filing cabinet and/or password protected computer files. Only my supervisor, Professor Rowena Cullen and I will have access to the data. The project will be submitted for marking to the School of Information Management and be deposited in the Victoria University Library. The contact details for a prize draw will be deleted after contacted the winner. The survey responses will be destroyed in two years. You can request the survey results and research report to get feedback by emailing me at the conclusion of the project. A summary report will be posted on the library website at the conclusion of the study.

Please note that you are under no obligation to take part in this research. If you have any questions, please feel free to contact Amanda HE at heying@myvuw.ac.nz or Rowena Cullen at rowena.cullen@vuw.ac.nz

Thank you for responding and for your valuable time. Yours Sincerely, Amanda HE 


\section{A.2 Reminder email}

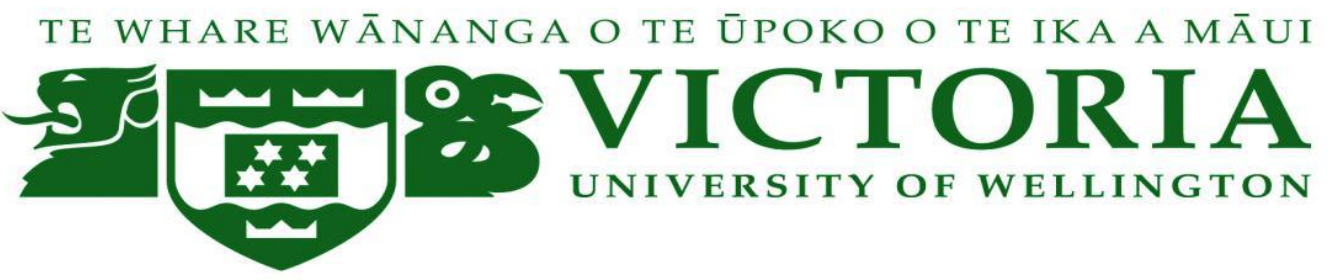

Dear Lincoln University Staff,

This e-mail is a reminder for you to participate in a research survey about what methods and tools are used by academics for information seeking and whether academics make optimum use of Lincoln University Library.

My name is Amanda HE. I am conducting this Research Project as part of my Master of Information Studies in Victoria University of Wellington.

This research has been approved by the University Librarian, Professor Penny Carnaby, and by the Human Ethics Committee in the School of Information Management at Victoria University.

If you have already completed the survey, please ignore this email,

If you have not completed the survey yet, you will have 3 more days to complete.

Please do participate because your information will help Lincoln University Library improve its collection and services to meet your needs in information in the future.

To participate please, click here.

Thank you, your contribution to this research is much appreciated.

Amanda He

Master of Information Studies

School of Information Management

Victoria University of Wellington 


\section{Appendix B}

\section{Questionnaire}

Thank you for accessing this survey!

Please complete this questionnaire to help us to find out how Lincoln University Library resources and services can work better for you!

*This survey is only about the Library side of Library, Teaching and Learning *

1. What is your department?

2. What is your position? (Please select one)

a Professor

- Associate/Assistant Professor

a Senior Lecturer

口 Lecturer

- Research Staff/Adjunct

a Other

3. How long have you been employed as an academic?

a Less than 5 years

व 5-10 years

口 11-15 years

- 16-20 years

21-25 years

๑ Over 25 years

4. Please indicate the time you spend using Lincoln University Library resources (total must equal 100\%).

口 $\%$ of my time is spent in the library.

a \% of my time is spent accessing library resources remotely (e.g. via the Internet from office, or from home, or traveling). 
5. Please indicate why are you visiting Lincoln University Library in person? (select all that apply)

\ With a class/meeting/seminars

口 Time out (e.g. lunch/breaks)

a Check out or return materials

- View new items (e.g. newspapers/display items)

- Availability of specific materials or information

ㄱo get help from Library staff

口 Using Wi-Fi service

口 Inter-loan service

口 Using equipment (e.g. computers/photocopiers)

a Other

6. Please indicate the time you spend using Lincoln University Library search engine and non-Lincoln University Library search engines (e.g. Google, Yahoo) to begin your information search (total must equal 100\%).

a _ _ of my time is spent using Lincoln University Library search engines (Library Search, the catalogues and other database on the LTL website).

口 \% of my time is spent accessing other non-library search engines (e.g. Google, Yahoo).

7. How often do you search other library catalogues (e.g. World Cat, public libraries, and other educational institutions) by using links provided by LTL website. (Please select one)

口 Daily

a Weekly

๑ Monthly

a Multiple times a semester

a Multiple times a year 
8. What format do you prefer to use in information-seeking?

a printed journals

口 electronic journals

a printed books

a electronic books

口 print abstracts \& indexes

口 online abstracts \& indexes

a manuscripts/primary documents

口 other____(please indicate)

9. Please select the devices you use most in accessing electronic resources?

a $\mathrm{PC}$

- Lap top

口 Smart phone

a ePad/tablet (e.g. iPad)

a eReader (e.g. Kindle, Kobo)

a Other (please indicate)

10. Please select the 3 methods you have used most to obtain information in the last 6 months.

a E-Meetings/Conferences

口 Emails

ㅁeleconferencing

a Fax

a Letters through the post

a Internet sources/web pages

a Personal Communications (oral)

口 Radio broadcasts

a Other (please write) 
11. Please indicate the uses you have made of the LTL (Library Teaching and Learning) website in the last 6 months (Please check all that apply)

- Search resources using "Library Search".

a Search electronically for journal articles using databases.

- Search the Lincoln University Library's catalogue.

- Search the catalogues of other libraries.

- Request interlibrary loans.

- Look for information about library polices, hours, and services.

- Set up course reserves.

- Arrange for bibliographic/information literacy instruction.

a Arrange for room bookings in the library

- Correspond with library staff/department liaison person.

a Obtain information concerning the appropriate utilization of copyrighted information.

- Find information about how to deposit research outputs in the Research Archive database.

- Obtain research assistance.

a Obtain accurate information about referencing.

口 Other (please specify) 
12. I have used the following library services/resources during the past 6 months (please check all that apply)

a Traditional printed resources (e.g. books, reference materials, periodicals)

口 Electronic databases/article indexes

a Electronic books (E-Books)

- Electronic journals (E-Journals)

a Special collections/rare books

a Video/ Audio materials (e.g. DVD,CD, Micro-fiche)

a Interlibrary loan

a Computer access

口 Laptop/technology equipment checkout

a Meeting/research space

a Facilities for class instruction

a Staff library introduction

a Reference service

口 Virtual reference service (e.g. "Ask us")

a Research Archive service

口 Other (please specify) 
13. Can you please select the 3 methods and sources you use most for keeping upto-date in your field?

- Scanning current issues of print and electronic journals

a Previous knowledge

a Attending professional conferences, seminars, and workshops

a Discussions with colleagues

口 Browsing web pages online

a Browsing Google scholar

- Browsing Other Online -Journals/database/archive

a Browsing web pages online

a Scanning recent issues of abstracting and indexing tools

a Through email alerts (RSS, Research alerts)

a Browsing publishers' catalogues.

a Reading latest books

a Browsing books in library

- Media: newspaper, TV and radio

a Consulting experts in subject field

a Using social networking website, such as Face-book, twitter, wikis etc

a Browsing blogs

口 Discussion with librarian or reference staff

口 Other (please indicate) 
14. Please select the 3 problems that you encounter most often when you are seeking information.

\begin{tabular}{|ll|cl|}
\hline$\square$ & $\begin{array}{l}\text { Required material is not } \\
\text { available }\end{array}$ & $\square$ & $\begin{array}{l}\text { Library staff are not } \\
\text { available }\end{array}$ \\
\hline$\square$ & $\begin{array}{l}\text { Information is scattered in too } \\
\text { many sources }\end{array}$ & $\square$ & $\begin{array}{l}\text { Lack of training in } \\
\text { electronic } \\
\text { resources/products }\end{array}$ \\
\hline$\square$ & $\begin{array}{l}\text { Information sources are very } \\
\text { expensive }\end{array}$ & $\square$ & $\begin{array}{l}\text { Library staff is incompetent } \\
\text { or not well-trained }\end{array}$ \\
\hline$\square$ & $\begin{array}{l}\text { Information sources are } \\
\text { located far away }\end{array}$ & $\square$ & $\begin{array}{l}\text { Lack of computer hardware } \\
\text { or software }\end{array}$ \\
\hline$\square$ & $\begin{array}{l}\text { Latest information sources are } \\
\text { not available }\end{array}$ & $\square$ & $\begin{array}{l}\text { Lack of technical support } \\
\text { much information }\end{array}$ \\
\hline$\square$ & $\begin{array}{l}\text { Information explosion or too } \\
\text { much }\end{array}$ & $\square$ & $\begin{array}{l}\text { Lack of information about } \\
\text { available sources }\end{array}$ \\
\hline$\square$ & $\begin{array}{l}\text { Lack of time for searching } \\
\text { library staff }\end{array}$ \\
\hline$\square$ & $\begin{array}{l}\text { Non availability of electronic } \\
\text { resource } \\
\text { (e-journals and databases) }\end{array}$ & $\square$ & $\begin{array}{l}\text { Lack of knowledge in using } \\
\text { the library }\end{array}$ \\
\hline$\square$ & Other & & \\
\hline
\end{tabular}


15. Please indicate the degree to which you agree or disagree with the following statements:

"I usually find library staff very helpful in answering my questions"

$\square$ strongly agree $\quad \square$ agree $\quad \square$ disagree $\quad \square$ strongly disagree

"I usually find the books I need at Lincoln University Library."

$\square$ strongly agree $\quad \square$ agree $\quad \square$ disagree $\quad \square$ strongly disagree

"I usually find the print periodicals and journals I need at Lincoln University Library."

$\square$ strongly agree $\quad \square$ agree $\quad \square$ disagree $\quad \square$ strongly disagree

"I can usually access the electronic resources I need (e.g. electronic databases, online indexes, e-journals, and e-books) through LTL web site."

$\square$ strongly agree $\square$ agree $\quad \square$ disagree $\square$ strongly disagree

"I usually find the materials I need via Google."

$\square$ strongly agree $\quad \square$ agree $\quad \square$ disagree $\quad \square$ strongly disagree

"I usually use library resources for keep up to date in my field."

$\square$ strongly agree $\quad \square$ agree $\quad \square$ disagree $\quad \square$ strongly disagree 


\section{(NOTE: PLEASE SKIP THE QUESTIONS BELOW, IF YOU ARE NOT TEACHING)}

16. When preparing a course Webpage, I provide links to electronic databases and other electronic resources available from Lincoln University Library...(select one)

$\square$ all courses $\quad \square$ more than half my courses $\quad \square$ less than half my courses more than

17. For courses that I teach, I utilize traditional (e.g. short-loan collection, books in the library) reserve services at Lincoln University Library...(select one)

$\square$ all courses $\quad \square$ more than half my courses $\quad \square$ less than half my courses more than

18. For courses that I teach, I recommend the use of electronic resources/databases at Lincoln University Library... ...(select one)

$\square$ all courses $\quad \square$ more than half my courses $\quad \square$ less than half my courses more than

19. Lincoln University Library has supported my teaching by........(check all that apply)

- Providing access to materials that have contributed to the conceptual framework of courses.

- Providing access to materials for inclusion in lectures and reading assignments.

- Purchasing print and electronic materials relevant to my field of study.

口 Providing access to subject databases and indexes.

- Providing information concerning the appropriate use and distribution of copyrighted materials.

- Providing information and assistance regarding the use of new resources.

a Providing information and assistance student research work.

口 Other (please specify)

\section{Submit Survey}




\section{Thank you very much for completing the survey!}

I appreciate the time you have spent on providing the information. This will definitely help Lincoln University Library improve the services for academic staff.

Please enter your name and contact information if you wish to be in the draw to win a prize of $\$ \mathbf{4 0}$ Gift card or receive a summary of this research.

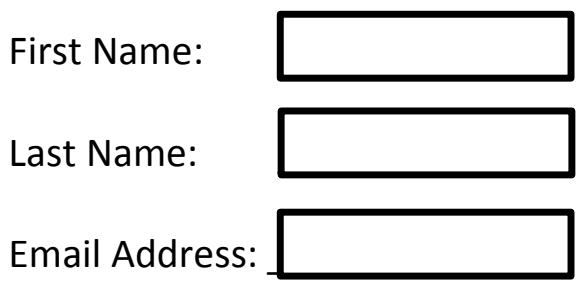

I would like to be in the draw to win a prize of $\$ 40$.

Yes or No

I would like to receive a summary of this research.

Yes or No 